HCP/T4014-01

UC-78

\title{
RADIATION LEVEL ASSESSMENT OF THE DRESDEN-1 DECONTAMINATION PILOT LOOP
}

May 1978

Prepared for

U.S. Department of Energy

Assistant Secretary for Energy Technology

Division of Nuclear Energy Development

Washington, D.C. 20545

Under Contract No. EY-76-C-02-4014

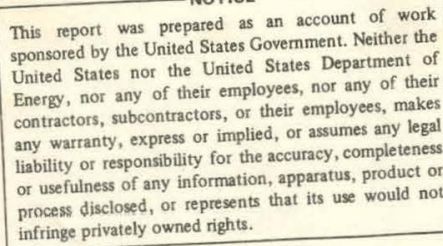




\section{DISCLAIMER}

This report was prepared as an account of work sponsored by an agency of the United States Government. Neither the United States Government nor any agency Thereof, nor any of their employees, makes any warranty, express or implied, or assumes any legal liability or responsibility for the accuracy, completeness, or usefulness of any information, apparatus, product, or process disclosed, or represents that its use would not infringe privately owned rights. Reference herein to any specific commercial product, process, or service by trade name, trademark, manufacturer, or otherwise does not necessarily constitute or imply its endorsement, recommendation, or favoring by the United States Government or any agency thereof. The views and opinions of authors expressed herein do not necessarily state or reflect those of the United States Government or any agency thereof. 


\section{DISCLAIMER}

Portions of this document may be illegible in electronic image products. Images are produced from the best available original document. 
HCP/T 4014-01

UC-78

\section{RADIATION LEVEL ASSESSMENT OF THE DRESDEN-1 DECONTAMINATION PILOT LOOP}

May 1978

Prepared by

General Electric Company

For

Commonwealth Edison Company

For the

U.S. Department of Energy

Assistant Secretary for Energy Technology

Division of Nuclear Energy Development

Washington, D.C. 20545

Under Contract No. EY-76-C-02-4014 
NOTICE

This report was prepared as an account of work sponsored by the United States Government. Neither the United States nor the United States Department of Energy, nor any of their employees, nor any of the contributors to this document, makes any warranty, expressed or implied, or assumes any legal liability or responsibility for the accuracy, completeness or usefulness of any information, apparatus, product or process disclosed, or represents that its use would not infringe privately owned rights. Reference herein to any specific commercial product, process, or service by trade name, mark, manufacturer, or otherwise, does not necessarily constitute or imply its endorsement, recommendation, or favoring by the United States Government or any agency thereof. The views and opinions of authors expressed herein do not necessarily state or reflect those of the U.S. Government or any agency thereof. 


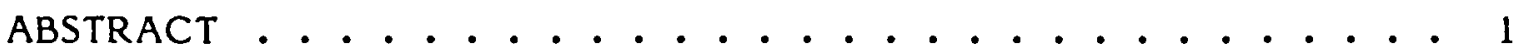

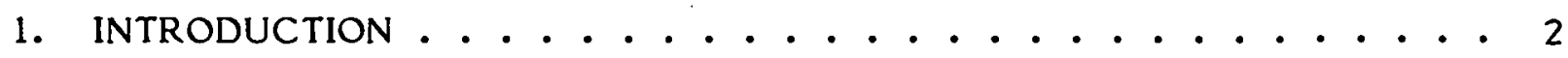

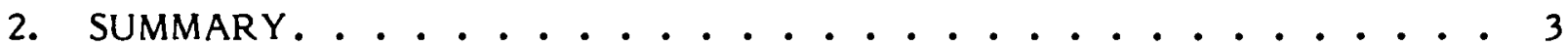

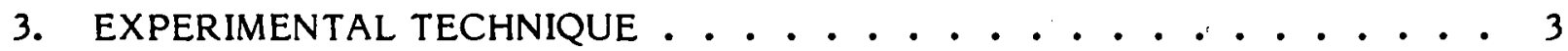

3.1 Pilot Demonstration Loop . . . . . . . . . . . 3

3.2 General Electric Ge(Li) Pipe Gamma Scanning System . . . . . . . 3

3.3 Experimental Procedure . . . . . . . . . . . 6

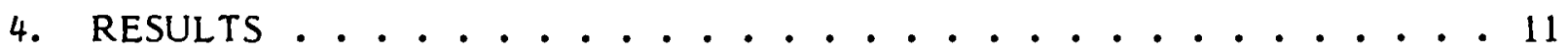

4.1 Spool Piece .................... 11

4.2 Pilot Loop . . . . . . . . . . . . . . . . 19

4.3 Error Analysis . . . . . . . . . . . . . 25

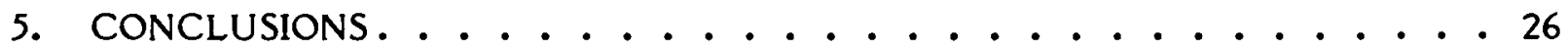

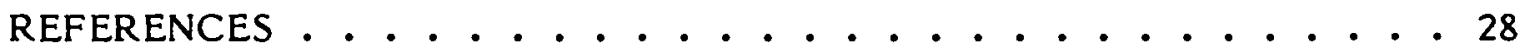
APPENDICES

A. Spool Piece Gamma Spectra - Section A . . . . . . . . . 29

B. Pilot Loop Gamma Spectra - Location $3 \ldots 34$ 


\title{
RADIATION LEVEL ASSESSMENT OF \\ THE DRESDEN-1 DECONTAMINATION \\ PILOT LOOP
}

\begin{abstract}
The radionuclide concentrations of the Dresden-1 decontamination pilot loop were determined by gamma spectroscopy. The General Electric Ge(Li) pipe gamma scanning system was utilized to take measurements at eight locations both before and after the pilot demonstration of decontamination process. Dose rate measurements were taken with a portable gamma monitor at 30 additional locations. The percentage of Co-60 removed was calculated and the results were interpreted.
\end{abstract}




\section{INTRODUCTION}

As a result of the increasing radiation levels of the primary components of Dresden Unit 1, the Commonwealth Edison Company ( $\mathrm{CECO}$ ) initiated a program to reduce the occupational radiation exposures by total plant decontamination. The Dow Industrial Service Division of Dow Chemical Company was selected as the prime contractor. After evaluating known decontamination technology, Dow recommended a chemical cleaning process utilizing Dow Solvent NS-1. An extensive materials testing program has been undertaken with reported favorable results to date. A pilot demonstration of the solvent and cleaning process using the old General Electric Task K - Corrosion Fatigue Loop at Dresden-1 was conducted from June 3 to June 16, 1976. Numerous corrosion specimens were subjected to the solvent and an examination of the loop piping and welds was performed before and after the test. A special spool piece containing sections of the 4-inch bypass line from Dresden-2 and -3, Monticello, and Quad Cities 2, and a new Dresden-1 safe end was fabricated and installed in the loop for the pilot demonstration.

The Nuclear Energy Systems Division of the General Electric Company is serving as a consultant to CECO for the decontamination project. One of the GE functions as a consultant was to measure the quantity and distribution of radionuclides present on the piping in the pilot loop and the spool piece both before and after the pilot demonstration. The experimental procedures and results of the baseline and after-cleaning mesurements are described. 


\section{SUMMARY}

Gamma scan measurements were taken at four locations on the pilot loop piping and four locations on the special spool piece both before and after the decontamination of the Dresden-1 pilot loop. The gamma scan measurements indicated greater than $90 \%$ of the Co-60 activity had been removed from the loop and spool piece. However, the dose rates determined with a portable gamma monitor (Cutie Pie) at 30 additional locations indicated a considerably lower percentage of the activity had been removed. Subsequent measurements with a directional probe demonstrated this inconsistency was due to external contamination in the loop area.

\section{EXPERIMENTAL TECHNIQUE}

\subsection{PILOT DEMONSTRATION LOOP}

The old General Electric Task K - Corrosion Fatigue Loop was constructed on Level 517 in the Dresden-1 sphere under an AEC contract. A schematic diagram of the loop ${ }^{1,2}$ is shown in Figure 1. During operation, coolant at $500^{\circ} \mathrm{F}$ and 1000 psig was withdrawn downstream from the outlet of the secondary heat exchanger, circulated through the loop, and then returned upstream of recirculation pump. The loop consists of three test vessels connected primarily with 1-1/2-inch-diameter pipe. The dynamic and static vessels were installed in 1969, while the crack propagation vessel was installed in 1974. A summary of the loop operating history 1,2 is given in Table 1 . Generally, when the loop was not in service it was drained and backfilled with either nitrogen or argon. The loop was decommissioned in June 1975 at which time it was turned over to CECO for the decontamination pilot test.

\subsection{GENERAL ELECTRIC Ge(Li) PIPE GAMMA SCANNING SYSTEM}

The General Electric Ge(Li) pipe gamma scanning system is shown in Figure 2. The specially designed detector and cryostat are shielded by 2.5 inches of Hevimet which provides approximately a 250-fold reduction of the Co-60 photopeak intensity. The detector is collimated by utilizing a series of Hevimet plugs with apertures ranging in diameter from 0.7 to $3.7 \mathrm{~cm}$. The detector output is processed by a multichannel analyzer, and the resultant gamma ray spectrum is analyzed for significant gamma-ray photopeaks by a programmable calculator. The calculator then prints out the gamma photopeak energy, the background counts, the total counts, and the counts per minute. The spectrum is also plotted with an $X-Y$ recorder. 
The pipe scanning system has been calibrated at General Electric's Vallecitos Nuclear Center for each aperture for a variety of pipe sizes and distances. ${ }^{3}$ These calibration data allow the net counts per minute data to be converted to microcuries per square centimeter for each photopeak identified. The net count rate is determined by subtracting the background count rate measured with a solid plug (that is, with the detector totally shielded) from the count rate measured with the test aperture.

TABLE 1. Dresden Test Loop Operating Summary

\begin{tabular}{|c|c|c|c|c|}
\hline $\begin{array}{l}\text { Loop } \\
\text { Operating } \\
\text { Period } \\
\end{array}$ & Startup & Shutdown & $\begin{array}{c}\text { Cumulative } \\
\text { Operating } \\
\text { Time (days) } \\
\end{array}$ & Remarks \\
\hline I & $9 / 16 / 70$ & $10 / 2 / 70$ & 17 & \multirow{3}{*}{$\begin{array}{l}\text { Loop shutdown in anticipation of } \\
\text { scheduled plant maintenance outa } \\
\text { Loop shutdown in anticipation of } \\
\text { scheduled plant maintenance outa } \\
\text { Loop shutdown to repair leaking } \\
\text { fitting. }\end{array}$} \\
\hline II & $10 / 72 / 70$ & $11 / 5 / 70$ & 32 & \\
\hline III & $11 / 25 / 70$ & $12 / 31 / 70$ & 69 & \\
\hline IV & $1 / 7 / 71$ & $1 / 14 / 71$ & 76 & \multirow{5}{*}{$\begin{array}{l}\text { Loop secured after reactor scram. } \\
\text { Loop shutdown for scheduled } \\
\text { plant outage. } \\
\text { Loop secured to repair steam } \\
\text { leaks and install cubicle air monitor. } \\
\text { Loop automatically isolated due to } \\
\text { low pressure trip. } \\
\text { Loop secured after reactor scram. }\end{array}$} \\
\hline V & $1 / 27 / 71$ & $2 / 3 / 71$ & 84 & \\
\hline VI & $2 / 17 / 71$ & $2 / 18 / 71$ & 85 & \\
\hline VII & $6 / 3 / 71$ & $6 / 23 / 71$ & 105 & \\
\hline VIII & $6 / 29 / 71$ & $8 / 12 / 71$ & 150 & \\
\hline IX & $3 / 24 / 72$ & $4 / 14 / 72$ & 171 & \multirow{5}{*}{$\begin{array}{l}\text { Loop secured after reactor scram. } \\
\text { Loop secured for plant shutdown. } \\
\text { Loop shutdown to repair leaking } \\
\text { fitting. } \\
\text { Loop shutdown to sealweld leaking } \\
\text { fittings. }\end{array}$} \\
\hline$X$ & $5 / 10 / 72$ & $5 / 12 / 72$ & 173 & \\
\hline$X I$ & $5 / 25 / 72$ & $5 / 26 / 72$ & 173 & \\
\hline XII & $6 / 16 / 72$ & $7 / 10 / 72$ & 198 & \\
\hline XIII & $12 / 8 / 72$ & & & \\
\hline $\mathrm{X} 111$ & & $2 / 4 / 73$ & 256 & Loop secured for plant shutdown. \\
\hline XIV & $2 / 8 / 73$ & $3 / 16 / 73$ & 292 & Loop secured for plant shutdown. \\
\hline$x V$ & $5 / 9 / 73$ & $6 / 13 / 73$ & 327 & Loop secured for plant shutdown. \\
\hline$X V I$ & $8 / 7 / 74$ & $8 / 13 / 74$ & 333 & $\begin{array}{l}\text { Dynamic Test Vessel remained out } \\
\text { of service. }\end{array}$ \\
\hline XVII & $1 / 29 / 75$ & $3 / 18 / 75$ & 381 & Final Operating Period. \\
\hline
\end{tabular}




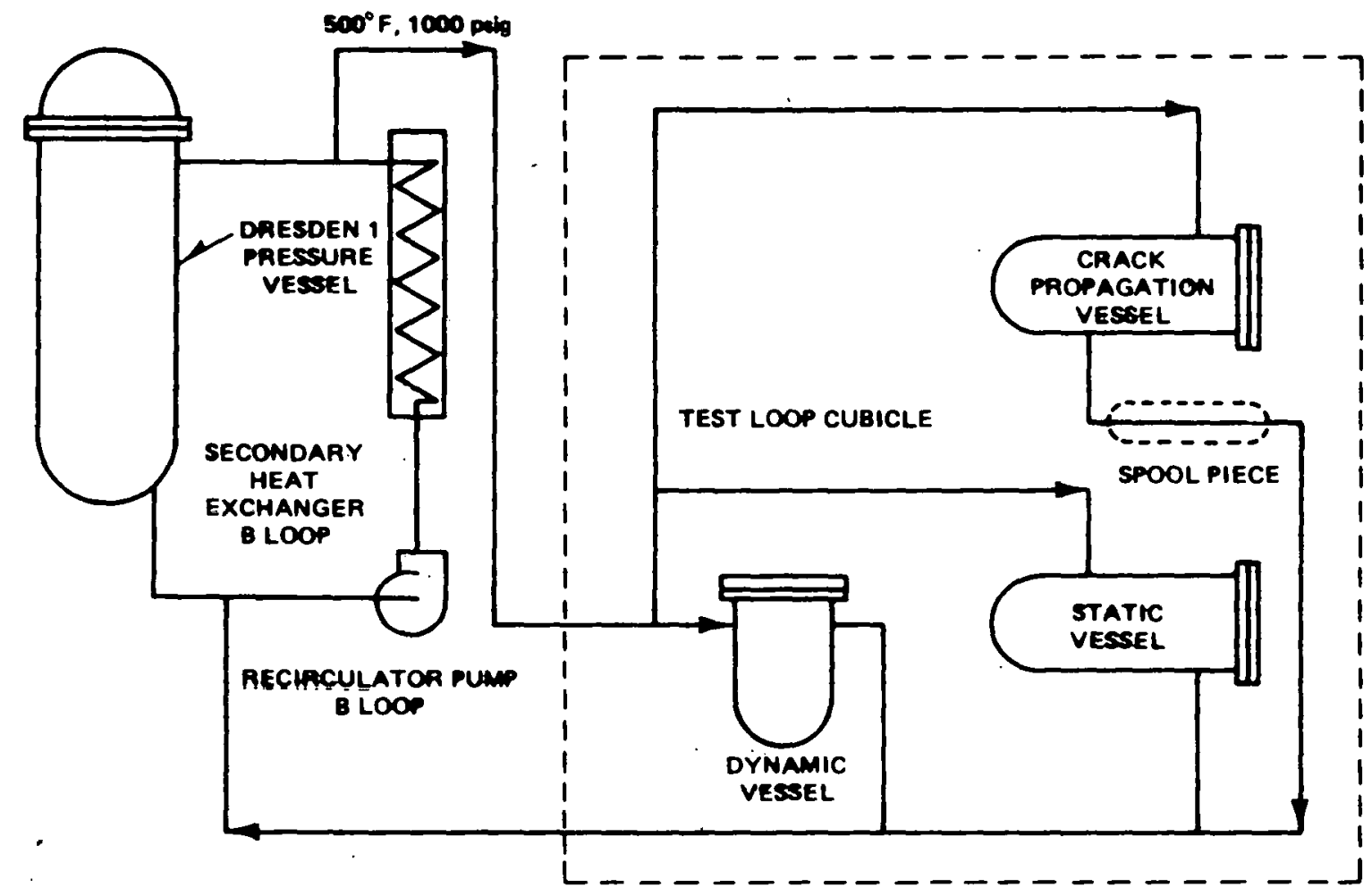

FIGURE 1. GENERAL ELECTRIC TASK K - CORROSION FATIGUE LOOP

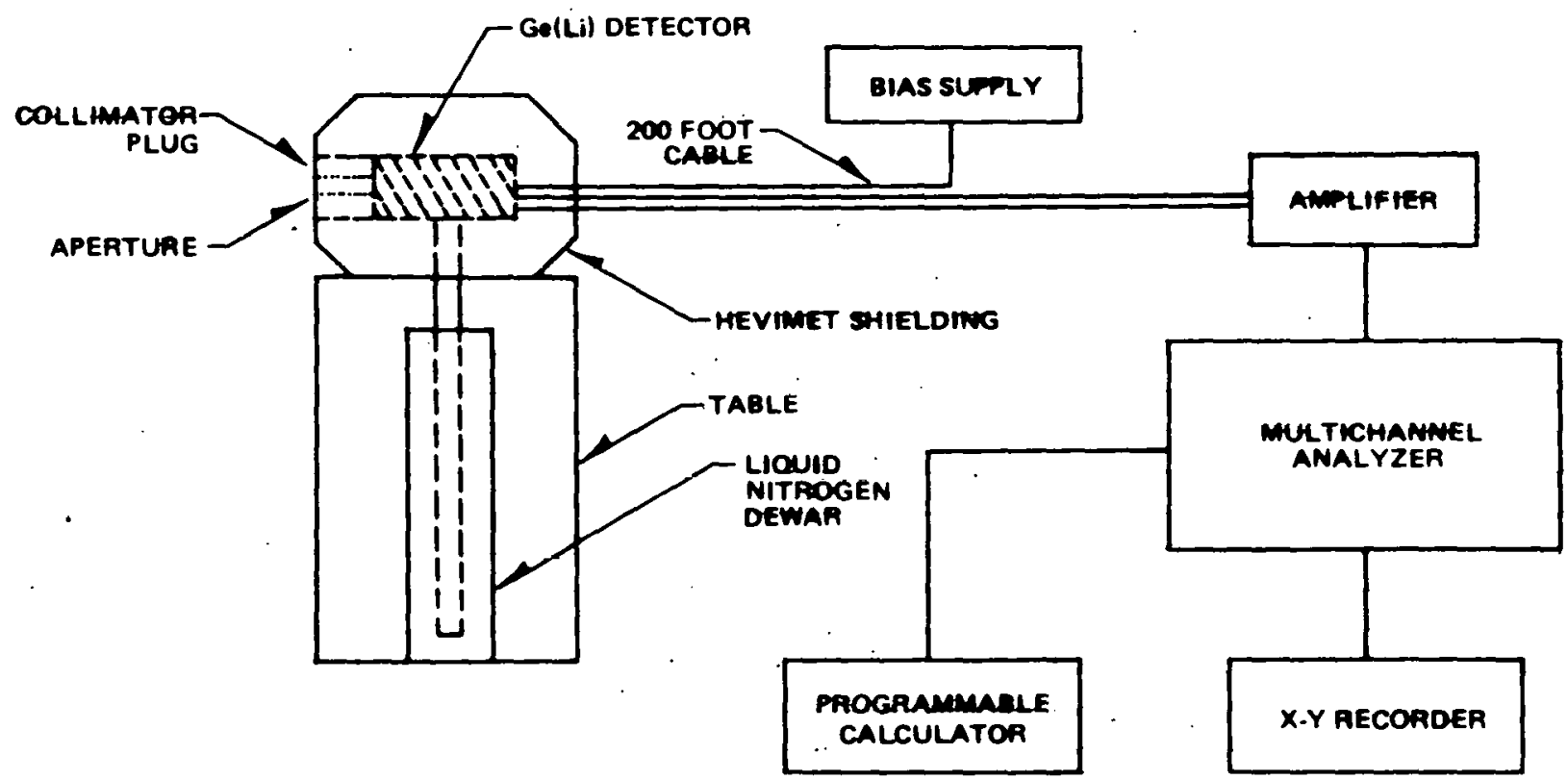

FIGUAE 2. GENERAL ELECTRIC Ge(LI) PIPE GAMMA SCANNING SYSTEM 


\subsection{EXPERIMENTAL PROCEDURE}

Eight target locations were gamma scanned both before and after the pilot demonstration. The experimental procedure, including the geometrical configuration of each scan, was identical for the two sets of measurements, with the exception that a 2-inch-thick lead brick was attached to the piping behind the target area for the second set of measurements on the pilot loop piping. All eight scans were taken using aperture No. 2 $(1.23 \mathrm{~cm}$ diameter) and were for 20 minutes. All eight background scans taken with the solid plug were for 10 minutes. A summary of the experimental conditions is given in Tables 2 and 3 for each of the eight gamma scans.

TABLE 2. Experimental Conditions Pilot Loop Gamma Scans

\begin{tabular}{|c|c|c|c|c|}
\hline Number & Location & $\begin{array}{l}\text { Shielding } \\
\text { to Pipe } \\
\text { Distance } \\
\text { (inches) } \\
\end{array}$ & $\begin{array}{l}\text { Height } \\
\text { above } \\
\text { Floor } \\
\text { (inches) }\end{array}$ & $\begin{array}{c}\text { Year } \\
\text { Installed }\end{array}$ \\
\hline 1 & Static Vessel, Outlet & $5-1 / 2$ & 30 & 1969 \\
\hline 2 & Dynamic Vessel, Inlet & $4-1 / 2$ & 30 & 1969 \\
\hline 3 & $\begin{array}{l}\text { Crack Propagation } \\
\text { Vessel, Outlet }\end{array}$ & $3-3 / 4$ & 53 & 1974 \\
\hline 4 & $\begin{array}{l}\text { Crack Propagation } \\
\text { Vessel, Inlet }\end{array}$ & $26-1 / 2$ & 53 & 1974 \\
\hline
\end{tabular}

TABLE 3. Experimental Conditions Spool Pieces Gamma Scans

\begin{tabular}{|c|c|c|c|c|c|}
\hline $\begin{array}{c}\text { Scan } \\
\text { Number } \\
\end{array}$ & $\begin{array}{c}\text { Sample } \\
\text { Identification } \\
\end{array}$ & Reactor & $\begin{array}{l}\text { Shiel ding } \\
\text { to Pipe } \\
\text { Distance }\end{array}$ & $\begin{array}{l}\text { Date of } \\
\text { Startup }\end{array}$ & $\begin{array}{c}\text { Date of } \\
\text { Pipe Removal } \\
\end{array}$ \\
\hline $\begin{array}{l}5 \\
6 \\
7 \\
8\end{array}$ & $\begin{array}{l}\mathrm{D} \\
\mathrm{C} \\
\mathrm{B} \\
\mathrm{A}\end{array}$ & $\begin{array}{l}\text { Dresden-3 } \\
\text { Dresden-2 } \\
\text { Quad Citics } 2 \\
\text { Monticello }\end{array}$ & $\begin{array}{l}\text { Contact } \\
\text { Contact } \\
\text { Contact } \\
\text { Contact }\end{array}$ & $\begin{array}{l}7 / 71 \\
4 / 70 \\
5 / 72 \\
3 / 71\end{array}$ & $\begin{array}{l}5 / 75 \\
1 / 75 \\
1 / 75 \\
1 / 75\end{array}$ \\
\hline
\end{tabular}

Four of the gamma scans were of the loop piping, of which two, the outlet line from the static vessel (Location 1) and the inlet line to the dynamic vessel (Location 2), were of the piping installed in 1969. The other two locations, the outlet (Location 3) and the inlet (Location 4) lines of the crack propagation vessel were of piping installed in 1974. The 
exact locations are shown in Figure 3. All four scans were of vertical runs of pipe. The detector aperture centerline was $45^{\circ}$ and $90^{\circ}$ from the inlet wall for Locations 1 and 2 , respectively, and was identical to the centerline of the crack propagation vessel for Locations 3 and 4 . The extremely crowded condition of the loop area prevented the movement of the assembled detector, therefore, it was necessary to assemble and disassemble the Hevimet shielding at each of the four locations. At Locations 1 and 2, the detector was set on a single layer of lead bricks; while at Locations 3 and 4 the detector was positioned on top of the lead brick shielding that surrounded the crack propagation vessel. The second gamma scan of the 1974 piping (Location 4) had to be taken at 26-1/2 inches from the shielding to pipe because of the difficulty of positioning the 350-pound shielding and detector.

The remaining four gamma scans were contact centerline scans of each of the four sections of recirculation bypass piping that made up the special spool piece. The target locations are shown in Figure 4. Before the post-decontamination gamma scanning of the spool piece, Dow personnel expressed concern about the spool piece being cleaned uniformly. They suspected it had not been completely vented and consequently only the bottom portion of the spool piece had been exposed to the solvent. To evaluate this possibility 1-minute scans with aperture No. 2 were taken at the top and bottom of each of the four spool piece sections. The detector was positioned so that the centerline of the aperture corresponded to a cord $1-1 / 2$ inches from the pipe centerline as shown in Figure 5. The distribution profile was also evaluated for the Monticello and Dresden-3 sections by taking 1-minute scans with aperture No. 2 at 1/4-inch intervals from the top position ( $1-1 / 2$ inches above the centerline) to the bottom position ( $1-1 / 2$ inches below the centerline). Background scans with the blank plug were not taken at any of these locations. The background count rate did not vary significantly (less than 10\%) across the profile, and thus, a more accurate value could be obtained by utilizing the centerline background count rate which was taken for a longer time period. Gamma scans with aperture No. 2 and the blank plug were also taken at the top (2-1/2 inches from the centerline) and bottom (2-1/2 inches from the centerline) of the weld in the safe-end at a distance of $2-1 / 8$ inches from the shielding to the safe-end.

Radiation level surveys were performed using a calibrated Cutie Pie before and after the pilot demonstration to measure the dose rate at 30 additional locations on the loop piping. All measurements were at contact with either the insulation or the exposed pipe. No particular attempt was made to locate "hot spots" in the piping or in the loop area. Also, the dose rates from the test vessels were not measured directly, since the test vessels 


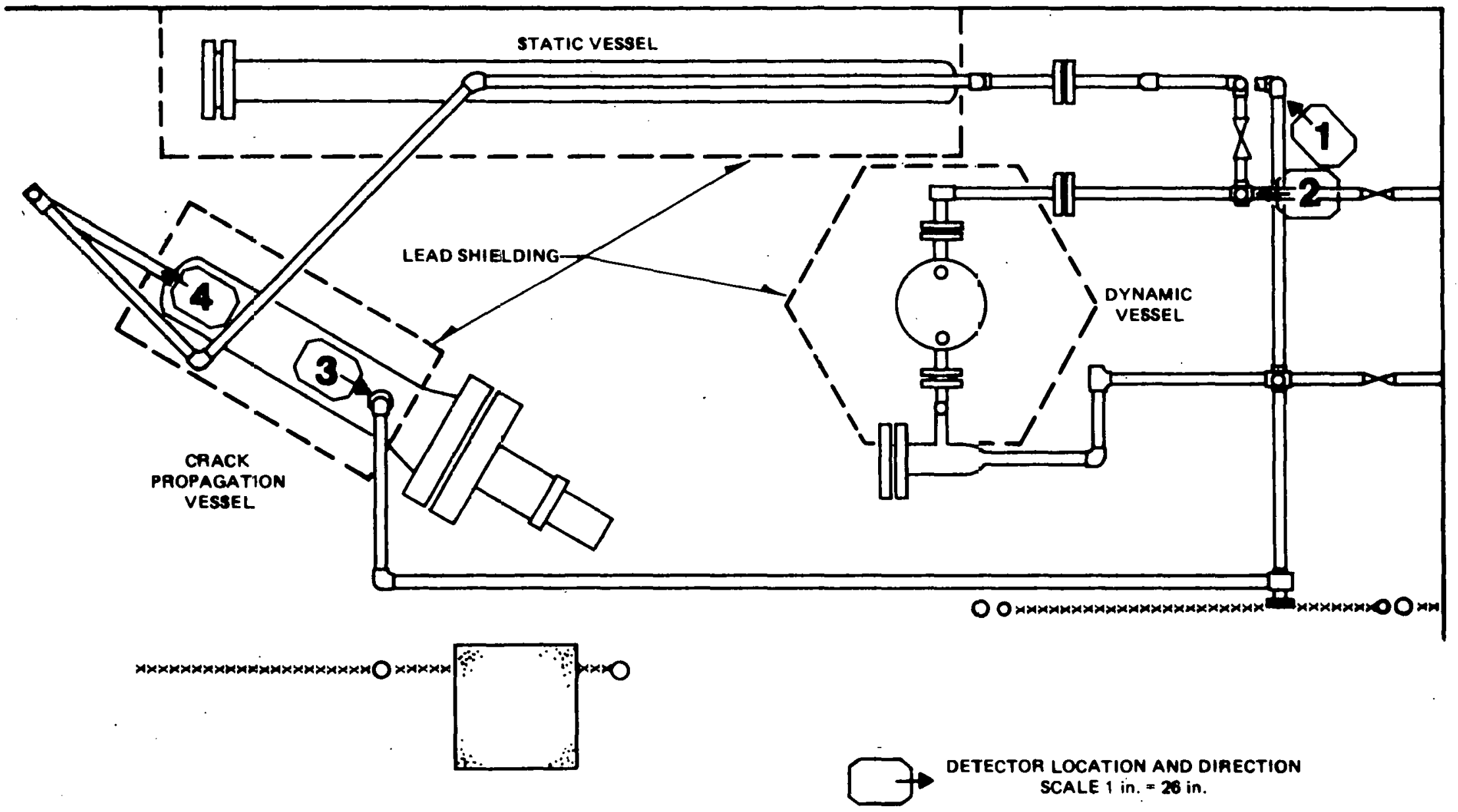

FIGURE 3. DRESDEN-1 DEZONTAMINATION PILOT TEST LOOP GENERAL ELECTRIC GAMMA SCAN LOCATIONS 

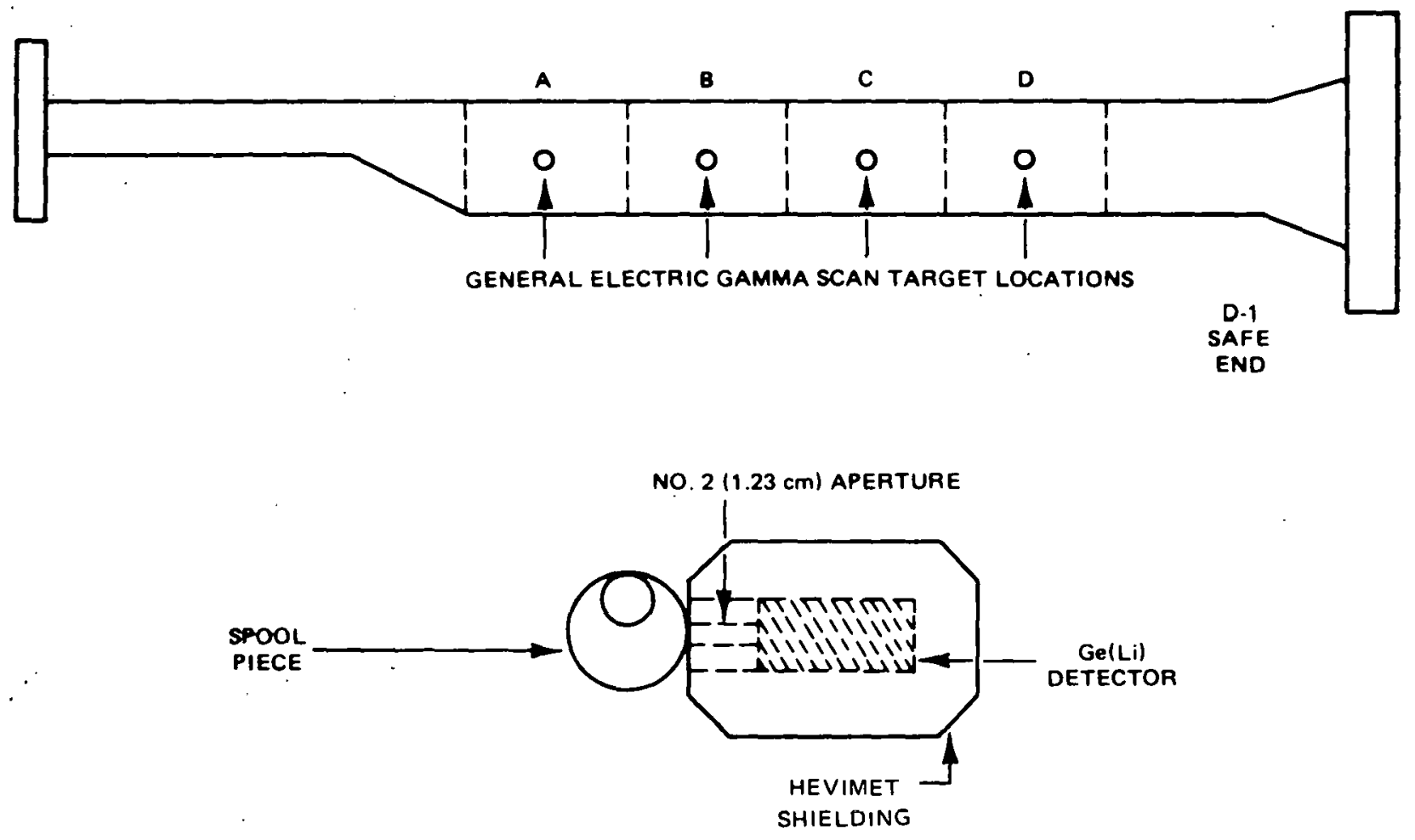

FIGURE 4. DRESDEN- 1 DECONTAMINATION PILOT TEST SPOOL PIECE (Four 6-inch Sections of 4-inch Schedule-80 Pipe) 


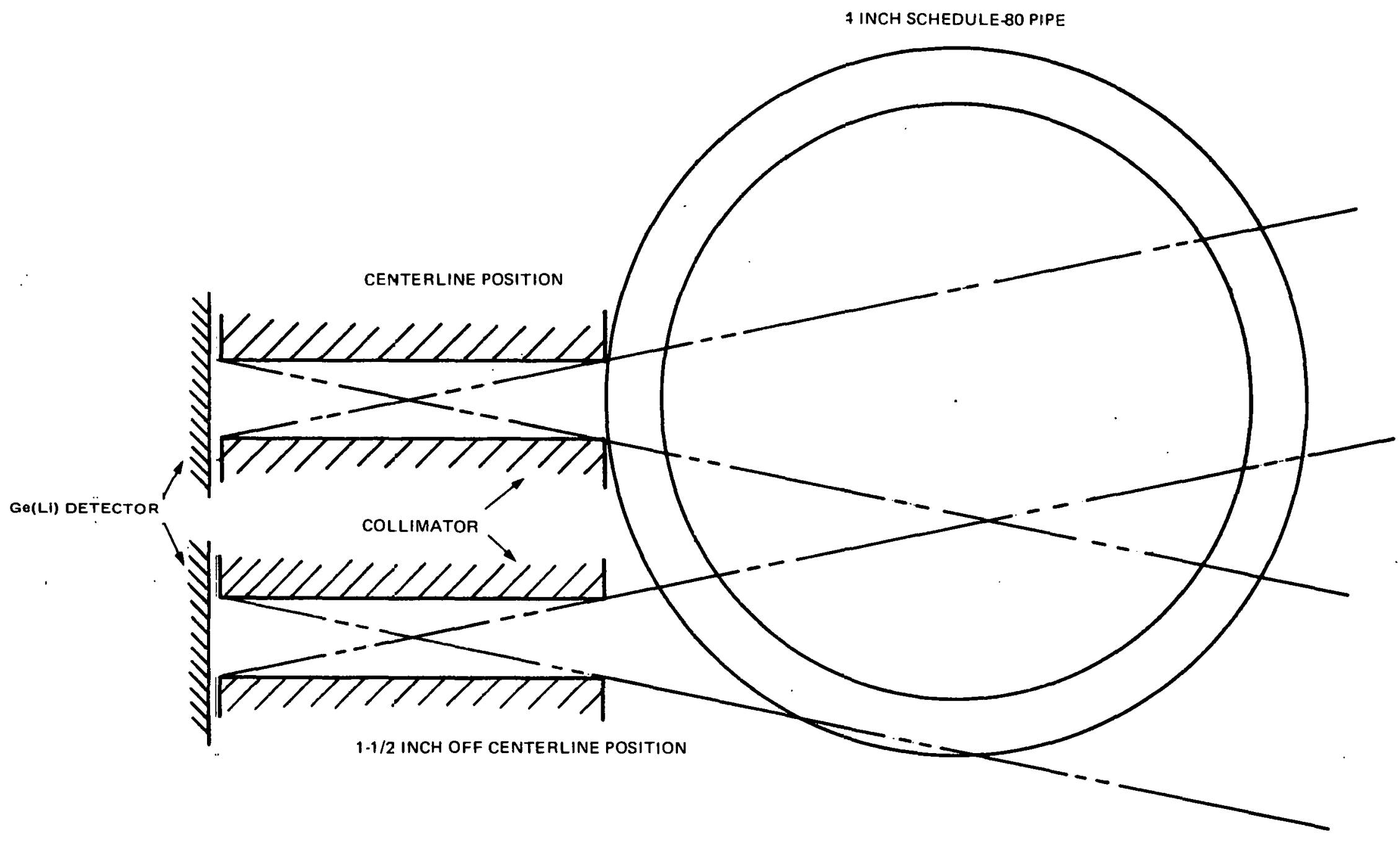

FIGURE 5. SPOOL PIECE CENTERLINE AND 1-1/2 INCH OFF CENTEF LINE GEOMETRIES 
were fully surrounded by lead at the time of the first survey and only partially shielded (most of the lead was removed for the pilot demonstration) during the second radiation level survey.

Two additional dose rate surveys were made to resolve an anomaly between the gamma scan and dose rate data sets (see Section 4.2 of this report for a complete discussion). The first survey taken in September 1976, after the loop area had been cleaned, consisted merely of repeating the Cutie Pie measurements at the thirty target locations. The second survey was conducted in December 1976 with a directional hand-held probe (Eberline HP22OA) modified with additional shielding. One inch of lead was added to the back of the detector and a 2-inch collimator with a 1-inch-diameter hole was added to the front. A series of 18 measurements of the loop piping was taken. Three measurements ( 1 minute each) were made at each location to establish the relative dose rates from the general background, the target pipe, and the environment behind the pipe. The geometric configurations for these three measurements are given in Figure 6. The dose rates were quantified by utilizing a scaler with digital readout. Additional background measurements were made at several locations to establish the sources of the residual dose rate.

\section{RESULTS}

\subsection{SPOOL PIECE}

The experimental results of the before and after gamma scans for the four sections of the special spool piece are given in Table 4. Greater than $90 \%$ of the Co-60 activity was removed from all four spool piece sections during the pilot demonstration. Gamma spectra for Section C (Dresden-2) are given in Appendix A.

The count rate data (Table 5) for the 1-minute of $\mathrm{f-centerline} \mathrm{scans} \mathrm{indicated} \mathrm{the} \mathrm{residual}$ activity was not uniformly distributed on all four sections. In each case, the bottom portion (as the spool piece was positioned in the loop) had a higher Co-60 concentration than the top portion. The 1-minute gamma scan profiles for the Monticello and Dresden-3 sections (Table 6) confirms this conclusion, since the profiles for the lower portions definitely had higher concentrations of Co- 60 . 
CONFIGURATION A

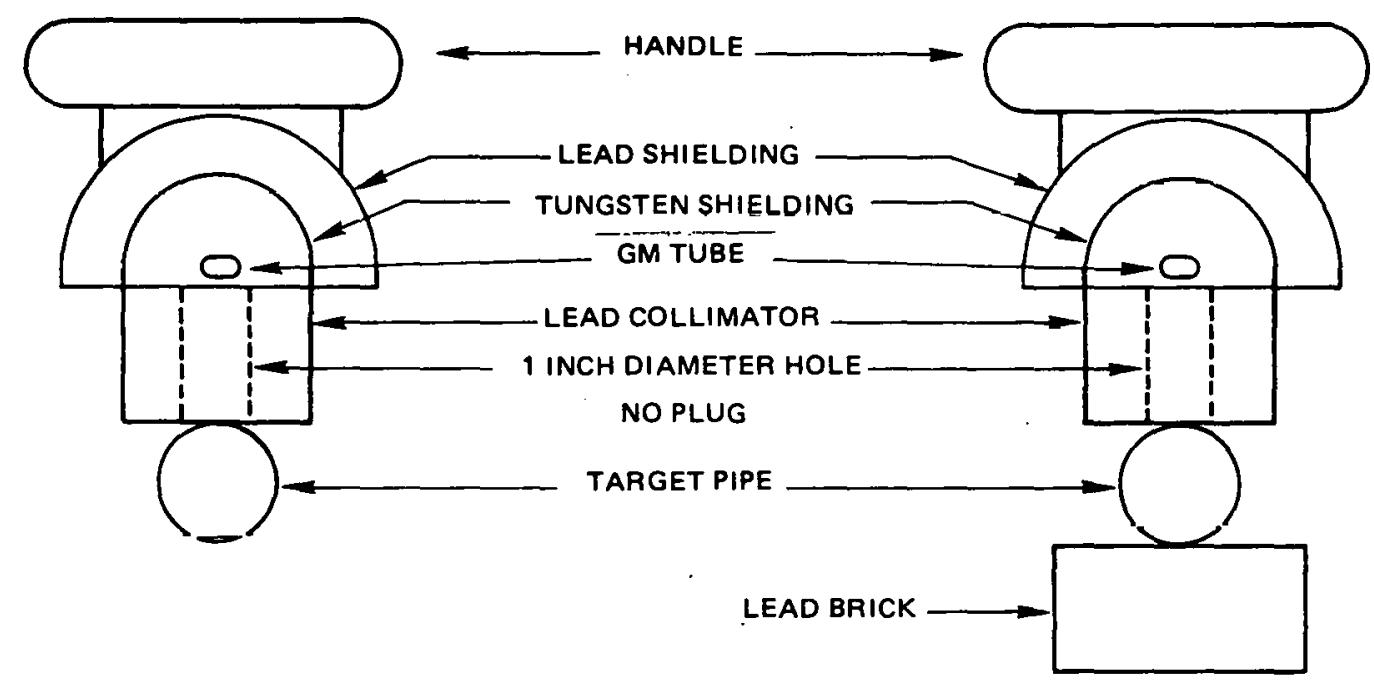

ENVIRONMENT

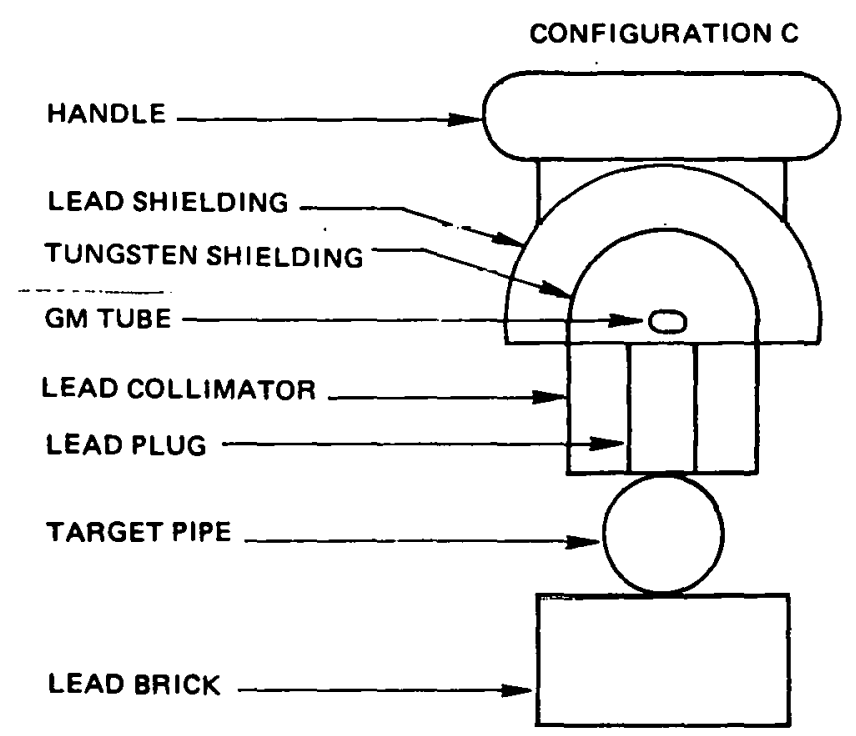

SCALE

$1 / 4$ inch $=1$ inch

ENVIRONMENT

FIGURE 6. DRESDEN-1 DECONTAMINATION LOOP - RADIATION LEVEL SURVEY CONFIGURATIONS 
TABLE 4. Spool Piece Gamma Scan Measurements

\begin{tabular}{|c|c|c|c|c|}
\hline \multirow[b]{2}{*}{ Section } & \multicolumn{3}{|c|}{ Radioisotopic Concentration $\left(\mu \mathrm{Ci} / \mathrm{cm}^{2}\right)$} & \multirow[b]{2}{*}{$\begin{array}{c}\text { Percent } \\
\text { Removed }\end{array}$} \\
\hline & & $\begin{array}{c}\text { Before } \\
\text { Decontamination }\end{array}$ & $\begin{array}{c}\text { After } \\
\text { Decontamination }\end{array}$ & \\
\hline $\begin{array}{l}\text { Monticello } \\
\text { (A) }\end{array}$ & $\begin{array}{l}\mathrm{Co}-60 \\
\mathrm{Zn}-65 \\
\mathrm{Mn}-54\end{array}$ & $\begin{array}{l}2.9 \\
2.6 \\
0.06\end{array}$ & $\begin{array}{l}0.09 \\
0.10 \\
\text { N.D. }\end{array}$ & $\begin{array}{l}97 \\
96 \\
-\end{array}$ \\
\hline $\begin{array}{l}\text { Quad Cities } \\
\text { (B) }\end{array}$ & $\begin{array}{l}\mathrm{Co}-60 \\
\mathrm{Zn}-65 \\
\mathrm{Mn}-54\end{array}$ & $\begin{array}{l}5.7 \\
0.1 \\
0.15\end{array}$ & $\begin{array}{l}0.31 \\
0.056 \\
0.012\end{array}$ & $\begin{array}{l}95 \\
44 \\
92\end{array}$ \\
\hline $\begin{array}{l}\text { Dresden-2 } \\
\text { (C) }\end{array}$ & $\begin{array}{l}\mathrm{Co}-60 \\
\mathrm{Mn}-54\end{array}$ & $\begin{array}{l}3.5 \\
0.07\end{array}$ & $\begin{array}{l}0.33 \\
\text { N.D. }\end{array}$ & $\begin{array}{l}90 \\
-\end{array}$ \\
\hline $\begin{array}{l}\text { Dresclen-3 } \\
\text { (D) }\end{array}$ & $\begin{array}{l}C 0-60 \\
M n-54 \\
Z n-65\end{array}$ & $\begin{array}{l}8.9 \\
0.24 \\
\text { N.D. }\end{array}$ & $\begin{array}{l}0.88 \\
\text { N.D. } \\
0.086\end{array}$ & $\begin{array}{l}90 \\
- \\
-\end{array}$ \\
\hline
\end{tabular}

TABLE 5. Spool Piece Co-60 Distribution

\begin{tabular}{|c|c|c|c|c|c|c|}
\hline \multirow[b]{2}{*}{ Section } & \multicolumn{3}{|c|}{$\begin{array}{l}\text { Net Co-60 Count Rate } \\
(\mathrm{cpm})\end{array}$} & \multicolumn{3}{|c|}{$\begin{array}{c}\text { Average Co-60 Concentratio } \\
\left(\mu \mathrm{Ci} / \mathrm{cm}^{2}\right)\end{array}$} \\
\hline & Top & Middle & Bottom & Top & Middle & Bottom \\
\hline $\begin{array}{l}\text { Montirello } \\
\text { (A) }\end{array}$ & 75 & 159 & 415 & 0.03 & 0.09 & 0.19 \\
\hline $\begin{array}{l}\text { Quad Cities } \\
\text { (B) }\end{array}$ & 365 & 527 & 949 & 0.16 & 0.31 & 0.42 \\
\hline $\begin{array}{l}\text { Dresden-2 } \\
\text { (D) }\end{array}$ & 351 & 567 & 636 & 0.16 & 0.33 & 0.28 \\
\hline $\begin{array}{l}\text { Dresden-3 } \\
\text { (D) }\end{array}$ & $27 !$ & 1510 & 2828 & 0.12 & 0.88 & 1.22 \\
\hline $\begin{array}{l}\text { Dresden-1 } \\
\quad \text { Safe-End }\end{array}$ & 38 & & 126 & & & \\
\hline
\end{tabular}


TABLE 6. Spool Piece Gamma Scan Profiles

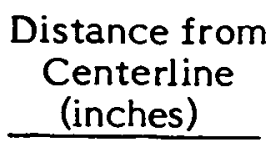

$+1-1 / 2$

$+1-1 / 4$

$+1$

$+3 / 4$

$+1 / 2$

$+1 / 4$

0

$-1 / 4$

$-1 / 2$

$-3 / 4$

$-1$

$-1-1 / 4$

$-1-1 / 2$

$\frac{\text { Monticello }}{\begin{array}{c}\text { Co-60 } \\ \text { Net Count Rate } \\ (\mathrm{cpm})\end{array} \quad \underline{\mathrm{Zn}-65^{\mathrm{a}}}}$

0.61

0.27

$-$

0.44

0.58

0.78

0.87

0.74

0.83

0.78

0.76

1.02

\begin{tabular}{|c|c|}
\hline \multicolumn{2}{|l|}{ Dresden-3 } \\
\hline $\begin{array}{c}\text { Co-60 } \\
\text { Net Count Rate } \\
(\mathrm{cpm}) \\
\end{array}$ & $\frac{\mathrm{Zn}-65^{\mathrm{b}}}{\mathrm{Co-60}}$ \\
\hline 274 & - \\
\hline 294 & - \\
\hline 334 & - \\
\hline 369 & - \\
\hline 474 & - \\
\hline 576 & - \\
\hline 798 & - \\
\hline 1107 & - \\
\hline 1527 & 0.15 \\
\hline 1995 & - \\
\hline 2528 & 0.09 \\
\hline 2816 & 0.08 \\
\hline 2728 & 0.08 \\
\hline
\end{tabular}

\footnotetext{
$\frac{\mathrm{Zn}-65}{\mathrm{C}-60}=0.90$ before decontamination. ${ }^{b} \mathrm{Zn-65}$ not detected in gamma scan before decontamination.
}

Calibration of the General Electric Ge(Li) pipe gamma scanning system for noncenterline geometries is possible, but has not been performed. However, even if this calibration were performed, quantitative interpretation of the data derived from a nonuniform and unknown distribution is extremely difficult, if not impossible. The complexity of this problem can be appreciated by examining Figure 5 which shows the portions of the pipe

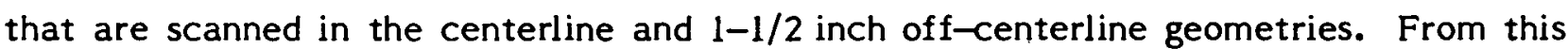
figure, it can easily be seen that changing the detector location not only changes the region being scanned, but also the shape of the pipe section being scanned. Average Co-60 concentration values for these irregular sections can be estimated by assuming the pipe activity distribution is uniform. However, developing a concentration profile from a series of these average concentrations is difficult; the areas overlap and are difficult to define mathematically. $\therefore$

Consequently, no attempt was made to convert the observed count rates from the Monticello and Dresden-3 profile scans to microcuries per square centimeter values. However, the count rate profile for a uniformly distributed source was determined by standard calibration techniques utilizing an Eu-152 source. The shape of this profile along with the net count rate profiles (normalized to unity at centerline) observed for the Monticello and Dresden-3 sections is given in Figure 7. Calibration data were also 


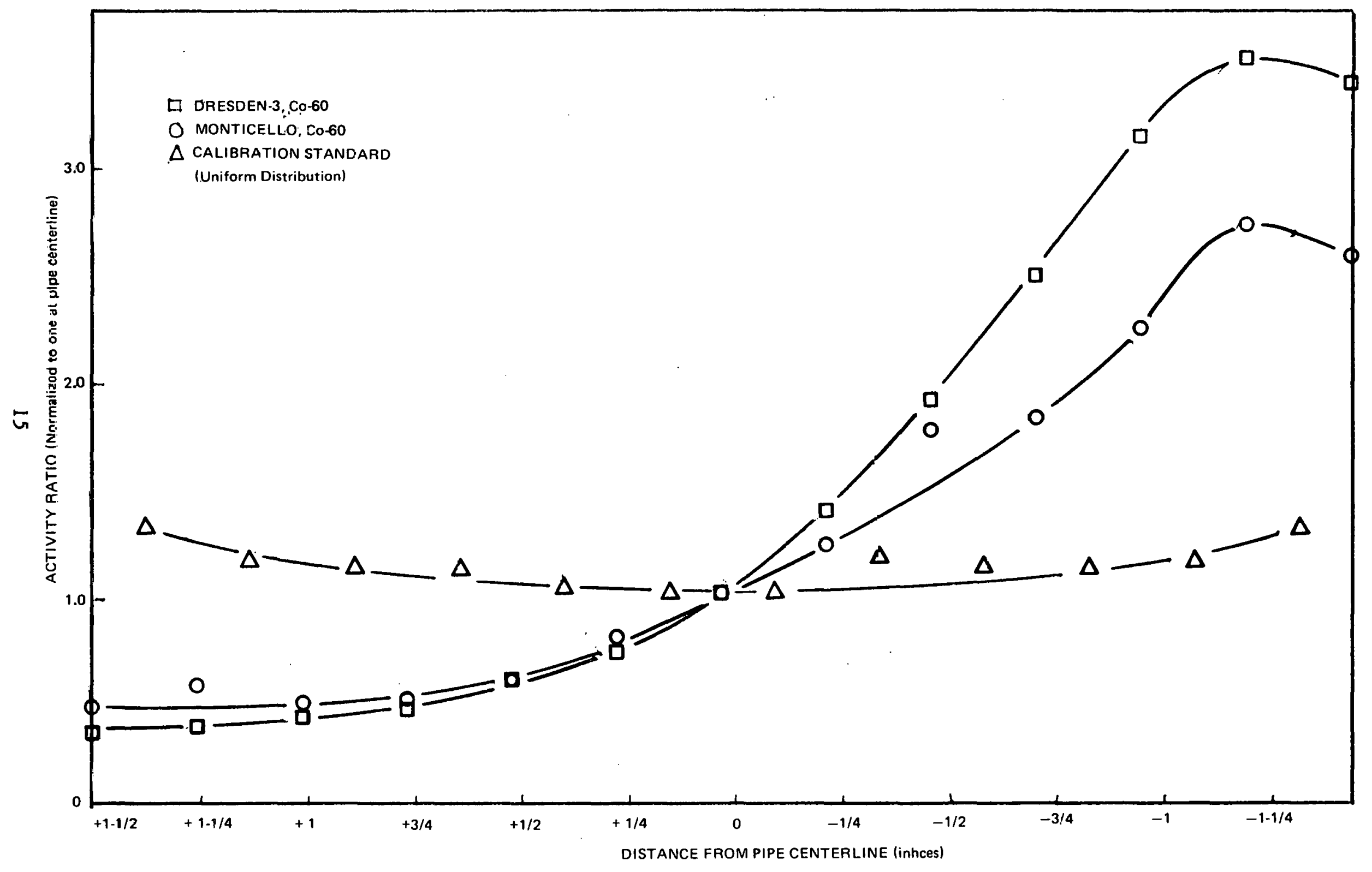

FIGURE 7. SPOOL PIECE ACTIVITY DISTRIBUTION PROFILES 
developed at the Vallecitos Nuclear Center for the $1-1 / 2$ inch of $f$-centerline geometric configuration. Values for the Co-60 concentration for the eight 1-minute scans are given in Table 5. However, because of the errors associated with their uncertain geometries, short count times, and nonuniform distributions, these 1 -minute top and bottom scans represent only an approximation, and should not be used to evaluate the decontamination process quantitatively.

The source of the residual activity on the spool piece can be determined by examining the radionuclide composition of the Monticello and Dresden-3 sections. Since the main condensor tubes at Monticello are made of admiralty brass, there is a significant elemental zinc input into the reactor vessel. The zinc deposits on the fuel and becomes activated. Zinc-65 is subsequently released to coolant and eventually becomes incorporated in the out-of-core deposits. Typically the Monticello out-of-core deposits contain roughly an equal amount of $\mathrm{Co}-60$ and $\mathrm{Zn}-65$. Since the other reactors represented in the pilot test do not have admiralty brass condenser tubes, their out-of-core deposit $\mathrm{Zn}-65-$ to-Co-60 ratio is considerably lower than that observed at Monticello. Consequently, the $\mathrm{Zn}-65$ can be used as tracer to ascertain where the residual activity on the spool piece originated. Since the $\mathrm{Zn}-65-$ to-Co-60 ratios of the Monticello and Dresden-3 sections of the spool piece were essentially unchanged during the decontamination, the residual activity must have originated from the same respective sections of pipe. Also since the $\mathrm{Zn}-65-$ to-Co-60 ratio of the residual activity on the Dresden-3 piece was 1 order of magnitude lower than on the Monticello piece, most of the residual activity could not be from ineffective rinsing or deposition of the circulating solvent.

Metallographic examinations of the inside diameter surfaces of the four recirculation loop 4-inch bypass lines that comprised the spool piece have been performed at General Electric. All four lines were fabricated from the same heat of material manufactured by the same vendor. Numerous short, transgranular, randomly oriented, 10-mil-deep penetrations were present on the inside diameter surfaces of all of this piping. These penetrations were present in the archive piping and were not due to exposure to $B W R$ coolant. Figure 8 shows the penetrations in the inside diameter surface at 10X; Figure 9 a cross-sectional view of the transgranular penetrations on the inside diameter surface at 10 and $500 \mathrm{x}$. The oxide film containing the activated corrosion products appears a relatively uniform thickness and coats the entire wetted surface including that of the penetrations. Examination of a section of the piping from Quad Cities 1 revealed approximately three-quarters of the activity was located in the penetrations. Thus, the four spool piece sections constituted difficult surfaces to decontaminate. 


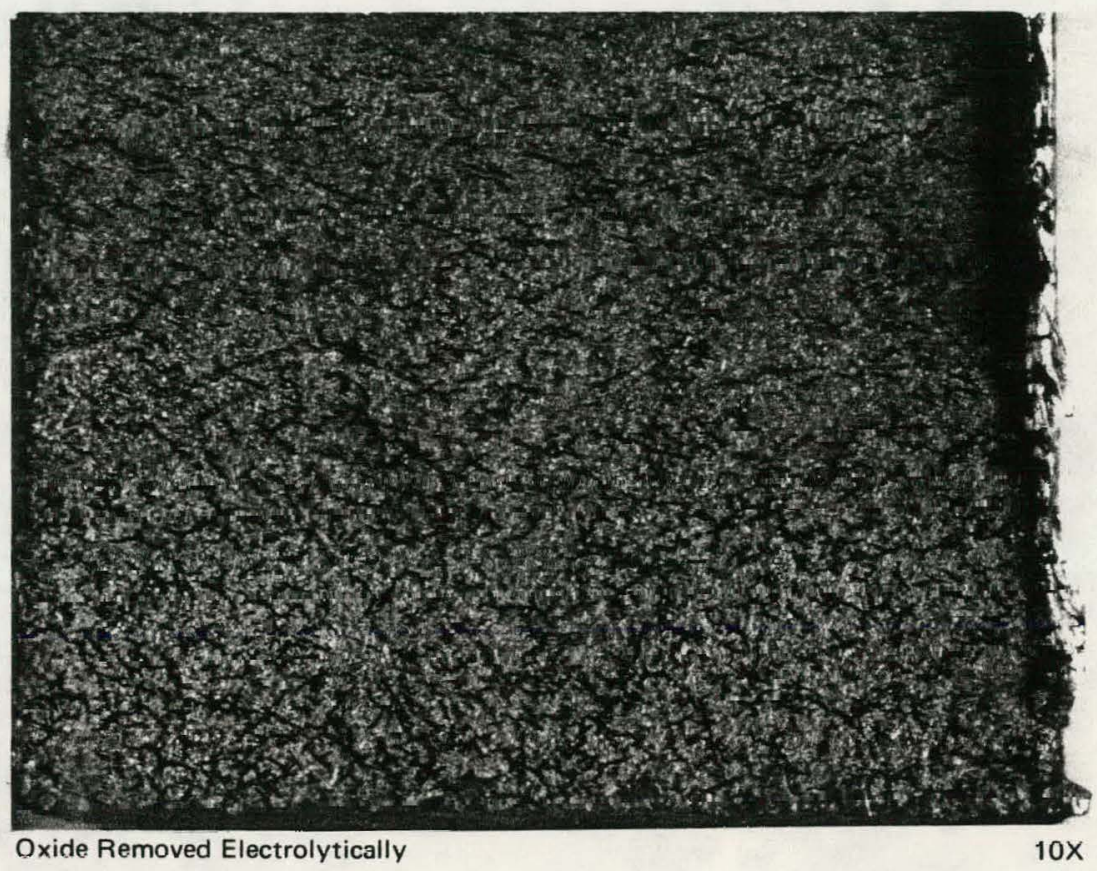

FIGURE 8. INSIDE DIAMETER SURTACL OT THE QUAD CITIES 1 RECIRCULATIUNN BYPASS LINE 


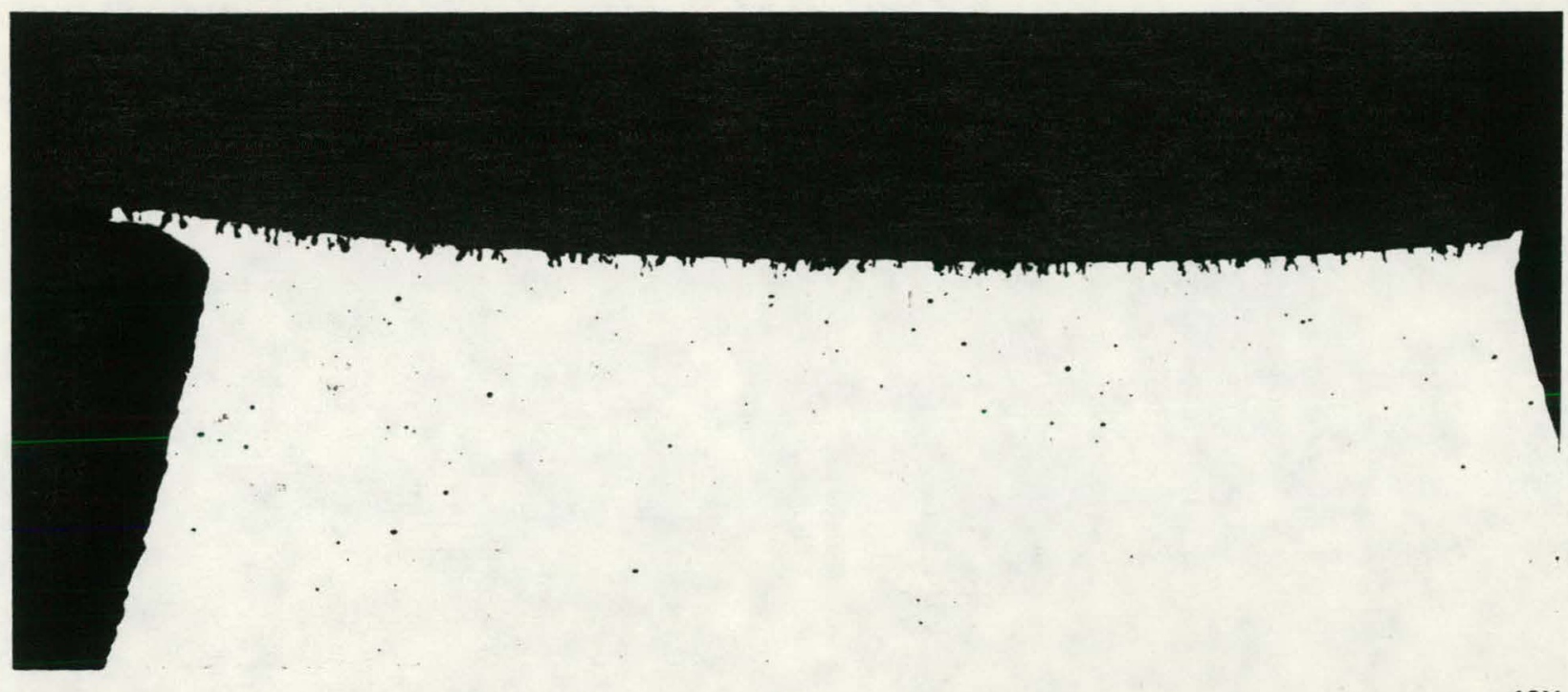

$10 x$

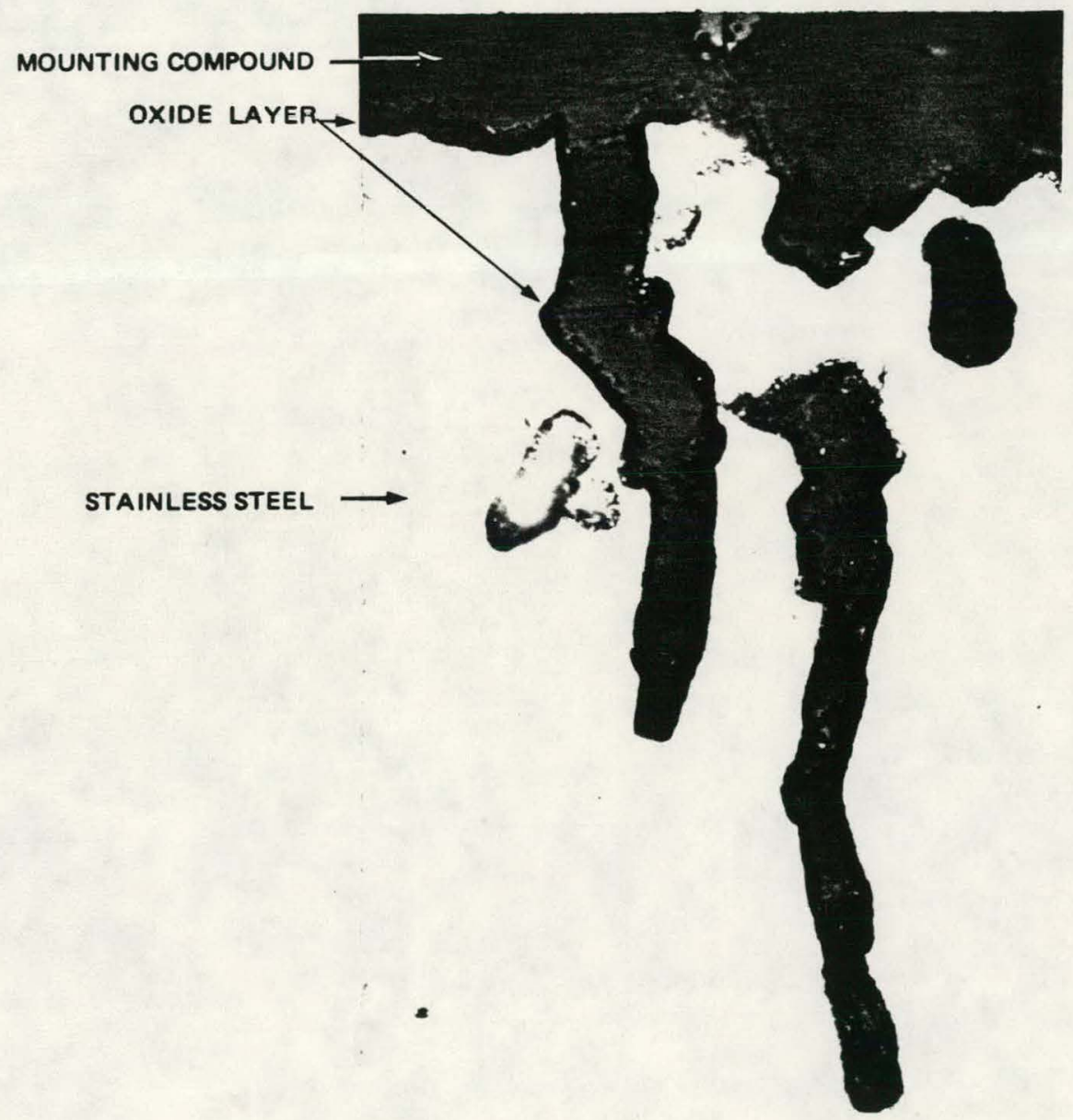

$500 x$

FIGURE 9. CROSS SECTION QUAD CITIES 1 RECIRCULATION BYPASS LINE 
Apparently the solvent (NS-1) was able to permeate the penetrations and dissolve the majority of the oxide film, but was only partially rinsed from the penetrations. The orientation of the irregular geometries should not have affected the dissolution properties of the solvent. However, gravity flow from the top penetrations would have aided in rinsing the upper penetrations, but not the lower penetrations. Thus, an activity gradient would have been developed across the pipe with the higher values located on the bottom surface.

The 1-minute gamma scan of the Dresden-1 safe-end, which had not been previously exposed to contaminated coolant, showed a residual Co-60 concentration approximately equal to that found on the loop piping and on the top portions of the spool piece sections. Thus, it would appear there was a relatively uniform residual level of activity on the entire loop. This activity was most likely due to the rinsing procedure, since the top of the safe-end was a factor of 4 lower than the bottorn por livi.

\subsection{PILOT LOOP}

The radiation levels in the loop area after the pilot demonstration appeared to be inconsistently high when compared to the quantities of radionuclides removed during the decontamination process. A plausible explanation for the high dose rates was external contamination; the loop area was known to have been grossly contaminated before the pilot demonstration and numerous leaks had occurred during the pilot test. A 2-inch-thick lead brick was attached to the pipe behind each target location to provide background shielding for the second set of scans. This procedural change was instituted to ensure the measurement of the residual activity (anticipated to be low level) on the piping was not adversely affected by the high background in the loop area. On the initial set of scans, it was assumed most of the activity in the loop area was contained within the pressure boundary of the loop and its location could be readily predicted. The four target locations were carefully selected to ensure there was no major radiation sources (such as, pipe or vessels) in the detector viewing cone. Normally, the count rate contribution from external contamination is minor when compared to the primary count rate due to the relatively intense source (the target piping) that is directly in front of the detector aperture. Also the target pipe partially shields the detector further minimizing the background affect. Thus, background shielding was not provided for the first set of scans.

The experimental results of the two sets of gamma scans of the pilot loop piping are given in Table 7. At three of the four target locations (1, 2, and 3) greater than $95 \%$ of the 
Co-60 activity had been removed from the piping; only $82 \%$ had been removed from target Location 4. The gamma ray spectrums for target Location 3 are given in Appendix B.

Sections of piping were removed from target Locations 3 and 4 and surveyed in the laboratory. Their dose rates, 3 and $25 \mathrm{mR} / \mathrm{h}$, respectively, confirmed the gamma scan results which indicated the residual activity level at Location 4 was approximately one order of magnitude higher than at the other three locations. ${ }^{4}$ The higher level at Location 4 was quite likely due to incomplete venting of the loop, which caused a waterfall effect in this vertical run of pipe.

TABLE 7. Pilot Loop Isotopic Compositions

\begin{tabular}{|c|c|c|c|c|}
\hline \multirow[b]{2}{*}{$\begin{array}{c}\text { Sran Number } \\
\text { (year installed) }\end{array}$} & \multicolumn{3}{|c|}{ Radioisotopic Concentration $\left(\mu \mathrm{Ci} / \mathrm{cm}^{2}\right)$} & \multirow[b]{2}{*}{$\begin{array}{c}\text { Percent } \\
\text { Removed }\end{array}$} \\
\hline & & $\begin{array}{c}\text { Before } \\
\text { Decontamination } \\
\end{array}$ & $\begin{array}{c}\text { After } \\
\text { Decontamination } \\
\end{array}$ & \\
\hline $\begin{array}{c}1 \\
(1969)\end{array}$ & $\begin{array}{l}\text { Co- } 58 \\
\text { Co- } 60\end{array}$ & $\begin{array}{l}0.11 \\
3.40\end{array}$ & $\begin{array}{l}\text { N.D. } \\
0.024^{b}\end{array}$ & $\overline{99}$ \\
\hline $\begin{array}{c}2 \\
(1969)\end{array}$ & $\begin{array}{l}\mathrm{Cs}-134 \\
\mathrm{Cs}(\mathrm{Ba})-137 \\
\mathrm{Co}-60\end{array}$ & $\begin{array}{l}0.04 \\
0.05 \\
1.45\end{array}$ & $\begin{array}{l}\text { N.D. } \\
0.012 \\
0.051\end{array}$ & $\begin{array}{l}- \\
76 \\
96\end{array}$ \\
\hline $\begin{array}{c}3 \\
(1974)\end{array}$ & $\begin{array}{l}\mathrm{Co}-58 \\
\mathrm{Co}-60\end{array}$ & $\begin{array}{l}0.05 \\
1.89\end{array}$ & $\begin{array}{l}\text { N.D. } \\
0.019\end{array}$ & $\overline{99}$ \\
\hline $\begin{array}{c}4 \\
(1974)\end{array}$ & Co- 60 & 3.26 & 0.583 & 82 \\
\hline & $\begin{array}{l}{ }^{a} \text { Not Detect } \\
{ }^{b}{ }_{1.173} \text { peak }\end{array}$ & ilized due to calc & tor error on 1.332 & \\
\hline
\end{tabular}

The results of the Cutie Pie radiation level surveys taken before and after the pilot loop decontamination are given in Table 8. The location of each measurement point is shown in Figure 10. The two sets of data should not be compared directly, since much of the lead shielding was moved between the two measurement dates. However, even allowing for higher initial dose rates, the observed dose rate reduction was considerably different than the reduction which was anticipated from the results of the gamma scans of the loop piping. Since the loop was known to be highly contaminated from past operational procedures, the high residual dose rate was generally attributed to external contamination. Consequently, personnel from CECO, DOW, and General Electric decided the best approach was to clean the loop area and repeat the radiation level survey. The repeat survey (Table 8) taken by General Electric personnel in September $1976^{5}$ indicated 
the area cleaning effort had resulted in essentially no reduction in the average dose rate measured at the 30 additional locations on the loop piping; thus, the anomaly had not been resolved.

TABLE 8. Pilot Loop Dose Rate Measurements ${ }^{\mathrm{a}}$

Location

.1974 Pipe

\begin{tabular}{cc}
$\begin{array}{c}\text { Before Decontamination } \\
(\mathrm{mR} / \mathrm{h})(3 / 76)\end{array}$ & $\begin{array}{c}\text { After Decontamination } \\
(\mathrm{mR} / \mathrm{h})(6 / 76)\end{array}$ \\
\hline
\end{tabular}

After Cleaning

$(\mathrm{mR} / \mathrm{h})(9 / 76)$

1

250

180

175

200

155

155

270

190

65

35

65

50

50

55

110

260

30

50

45

45

60
90

310

8

175

220

125

225

250

150

260

225

45

45

30

50

75

70

70

80

110

15

1969 Pipe

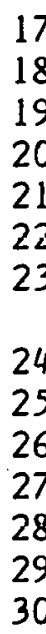

250

450

500

380

480

450

410

155

140

175

210

180

120

120

145

55

40

30

35

65

55

60

90

23

230

370

300

200

180

210

160

190

250

100

200

70

80

100

230

170

140.

70

80

125

200

105

100

280

70

70

30

${ }^{\mathrm{a}}$ The sets of dose rate data should not be compared directly, since lead shielding was moved between measurements. 


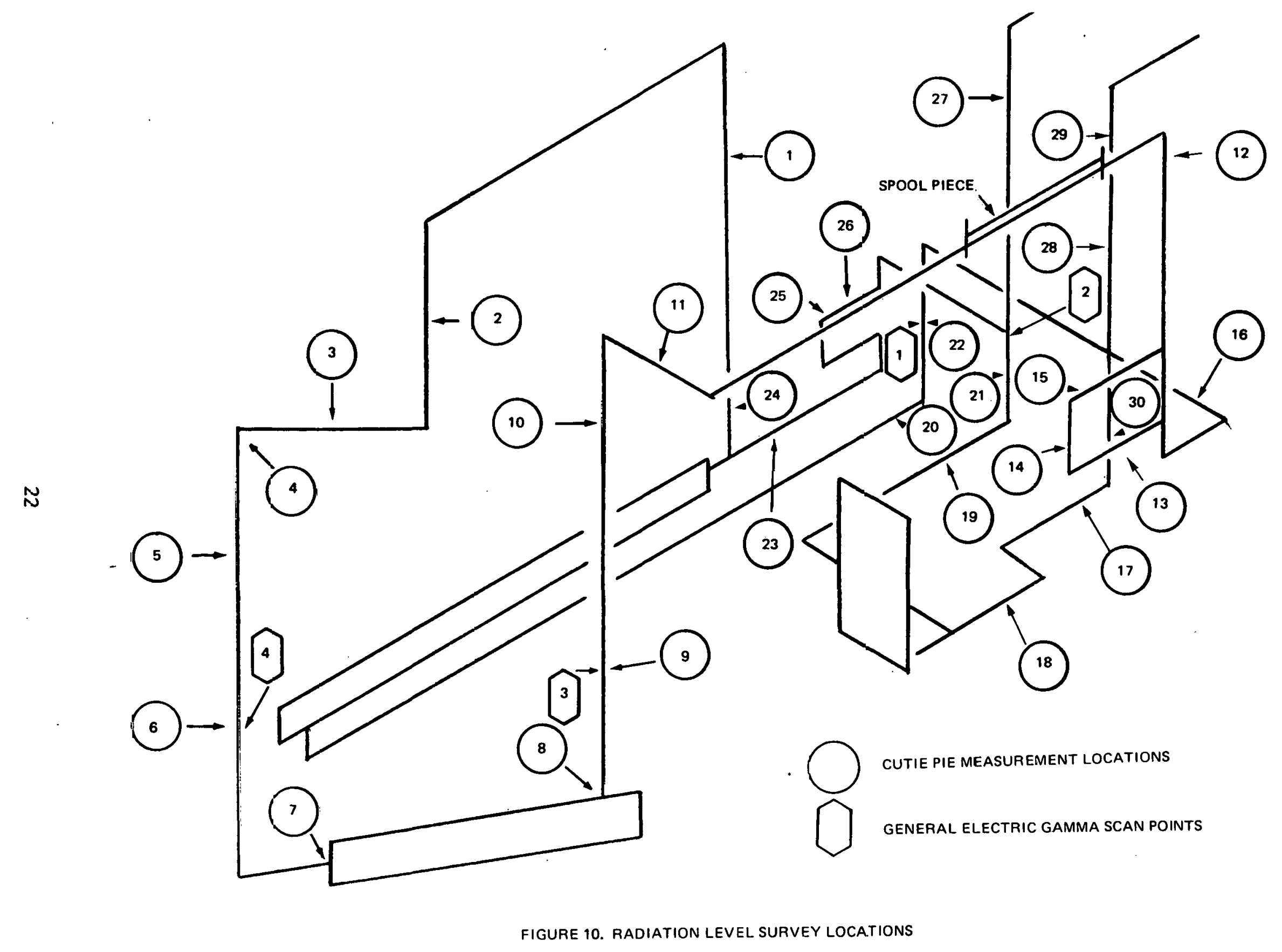


In December 1976, a four th radiation level survey was performed with the dual purpose of measuring the relative dose rates from the loop piping at a larger number (18) of locations and locating the sources of the high residual activity. The results (in counts per minute) of the 18 measurements are given in Table 9 along with their corresponding locations. These data show there was a low level of fairly uniform residual activity around the loop and support the previous gamma scan results by providing measurements of the piping at 14 more locations. No hot spots were observed on the loop piping.

TABLE 9. Pilot Loop Radiation Level Survey - Directional Probe

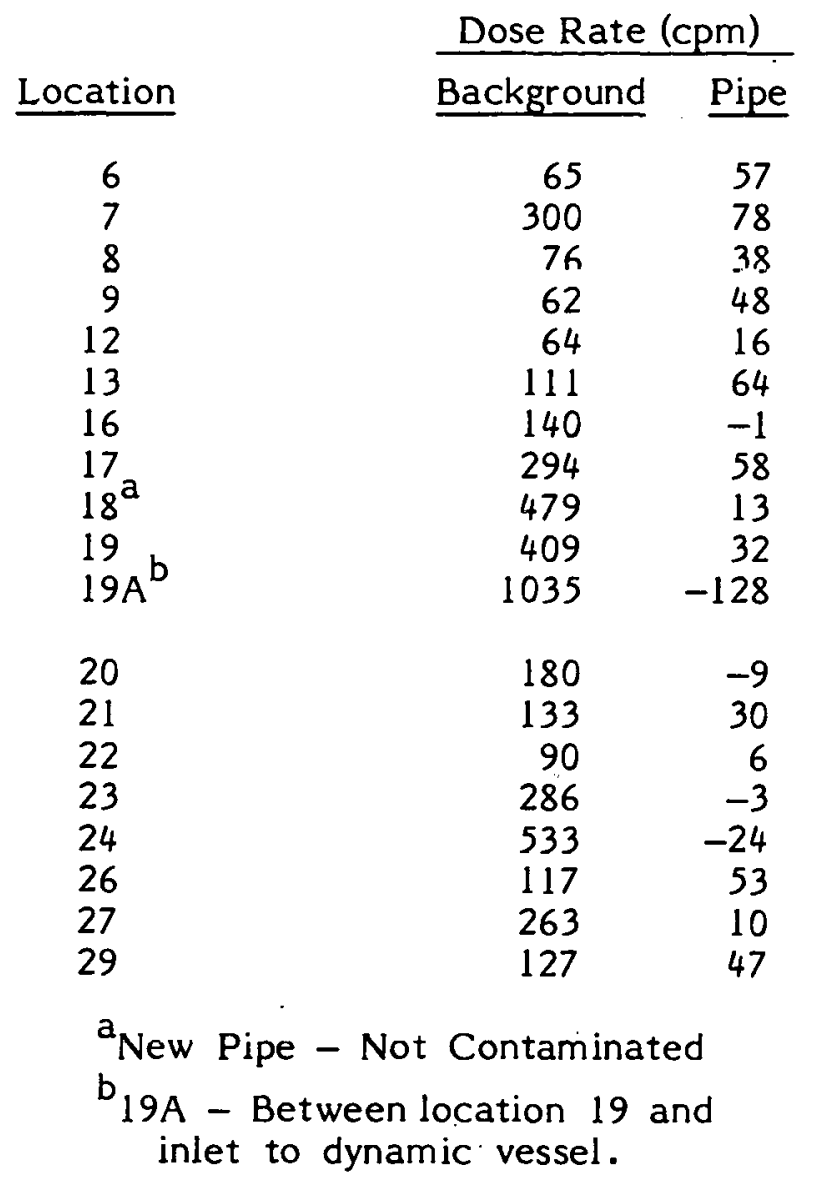

The background readings (configuration $C$ of Figure 6) with the plug in place showed a distinct pattern of activity (Figure 11) with major sources located around the dynamic vessel and under the flanged end of the static vessel. Subsequent Cutie Pie measurements indicated extremely high dose rates (greater than $1 \mathrm{R} / \mathrm{h}$ ) around the entire dynamic vessel. The dynamic vessel insulation, which was thoroughly soaked, was then removed from the vessel and placed in a plastic bag. The dose rate from the bag was $1.3 \mathrm{R} / \mathrm{h}$. The outside of the vessel was wet and extremely dirty, with indications that spills had occurred over 
DCISE RATE CONTOUR LINES

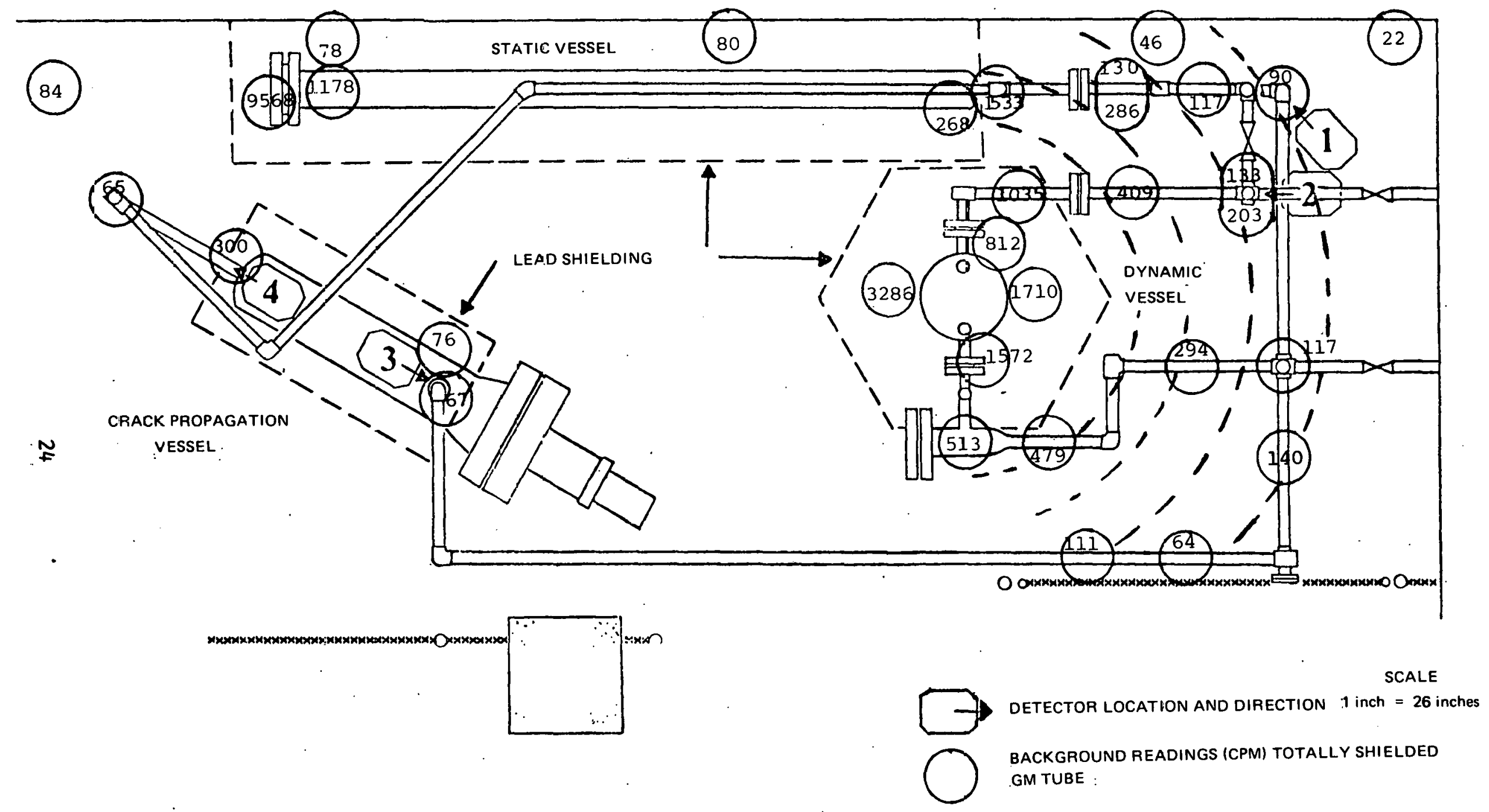

FIGURE 11. DRESDEN-1 DECONTAMINATION PILOT TEST LOOP RADIATION LEVEL SURVEY - BACKGROUND READINGS 
the years. Wiping of the vessel walls reduced the dose rate by approximately $40 \%$ (from approximately 600 to $350 \mathrm{mR} / \mathrm{h}$ ). The CECO personnel had previously measured the dose rate inside the vessel to be $230 \mathrm{mR} / \mathrm{h}$ and reported the inside vessel walls were clean. ${ }^{6}$

A second hot spot (greater than $5 \mathrm{R} / \mathrm{h}$ ) was located on the floor under the flange of the static vessel. The dose rates from the vessel itself (determined with the shielded probe) were orders of magnitude lower.

These data strongly support the hypothesis that the majority of the residual activity was external to the loop. However, absolute proof that there was no crud traps or hot spots remaining in the loop was not obtained. Absolute proof would have required cleaning the entire loop area to the extent that the external contamination was below the activity level defined as a hot spot. This task would have required extensive and costly additional efforts and was not deemed necessary because of the preponderance of evidence supporting the external contamination hypothesis.

In conclusion, the anomaly that existed between the gamma scan data and the dose rate measurement was due to contamination external (primarily on the insulation and floor) to the loop. Thus, while the residual dose rate in a decontaminated area should be a realistic measure of the effectiveness of the decontamination, this normal yardstick is not a fair measurement of the pilot decontamination. The excessive external contamination present in the pilot loop area may or may not be typical of the rest of the Dresden-1 plant, but its effect on the residual radiation levels will most certainly vary greatly throughout the plant. Thus, this contribution, which cannot be affected by the decontamination, should not be used to evaluate the decontamination pilot test. External contamination should be evaluated independently on a localized basis and appropriate cleaning efforts made so that the desired residual dose rates are obtained.

The Ge(Li) gamma scan results, supported by the shielded dose rate measurements at 18 locations, give a consistent analysis that indicates that greater than $90 \%$ of the activity was removed from the loop and that there was a relatively uniform, but low, level of Co-60 distributed throughout the loop.

\subsection{ERROR ANALYSIS}

A rigorous statistical analysis of the gamma scan data was not performed. However, the major errors associated with the $\mathrm{Ge}(\mathrm{Li})$ gamma scan measurement technique are counting statistics (approximately 3\% relative for the initial set of scans and 7 to $20 \%$ relative for 
the second set of scans), the detector calibration (less than $10 \%$ relative), the detector positioning (approximately 10\% relative), and the distribution of radionuclides on the piping (approximately 10\% relative). Combining these estimated errors gives a measurement of uncertainty of approximately $15 \%$ relative for the initial set of scans and. $25 \%$ relative for the second set of scans.

\section{CONCLUSIONS}

The major conclusions from the General Electric radiation level reduction measurements made before and after the pilot demonstration of the Dresden-1 decontamination process are:

1. The process appears capable of removing greater than $90 \%$ of the activity. This percentage was determined from the observed reduction in Co-60, which is the major radionuclide present on the Dresden-1 piping.

2. It appears the decontamination effectiveness will be partially determined by how well the system is vented and filled with solvent. If large portions of the reactor system are not fully covered with solvent the decontamination results may be considerably less than the $90+\%$ observed for the pilot demonstration.

3. The residual Co- 60 concentrations in the penetrations on the inside diameter surfaces of the four sections of the spool piece indicate the rinsing procedure may be inadequate for crevices (such as, socket welds) which cannot be thoroughly fluslied oi diained.

4. The relatively uniform, residual Co-60 concentration measured on the loop, on the top portion of the spool piece, and on the previously uncontaminated Dresden-1 safe-end indicates the decontamination process leaves a reasonably low level of residual activity on straight runs of pipes.

5. Based on the post-decontamination dose rate measurements, it appears external contamination may well be the limiting factor in the reduction of radiation levels at locations where there is excessive external contamination. The external contamination varies widely throughout the Dresden-1 reactor, and so will the impact of this contamination on the over-all success of the decontamination 
program. The pilot loop area probably represented one of the worst cases. Thus, the dose rate reduction (factor of 2 even though greater than $90 \%$ of the activity was removed from inside the loop) found in the external measurements of the pilot loop area (after a major portion of the lead had been removed) will most likely be at the lower end of the expected range of dose rate reductions. Cleaning of certain areas exhibiting high levels of external contamination may be required.

6. Because of the excessive external contamination present in the pilot loop area, extrapolation of the results of the pilot demonstration to the full plant decontamination is extremely difficult, since base line dose rate data for the clean piping without external contamination could not be obtained. While the gamma scan results give an indication of the cleaning effectiveness of the process, the true measure of the success of the decontamination program will be the residual dose rates throughout the Dresden-1 reactor. As discussed above, these dose rates will result from a combination of the residual internal activity and the external contamination. Prediction of the relative contributions will depend not only upon the uniformity of the cleaning process, that is, the vent and fill effectiveness, the flushing procedure and the number of crevices (some of which might be inadequately flushed), but also upon the distribution of residual external activity.

7. The quantitative evaluation of the radiation level reductions obtained in a nuclear power plant decontamination is extremely complex and requires a variety of different instruments for measuring radiation levels. Sophisticated directional $\mathrm{GE}(\mathrm{Li})$ systems with 2 to 4 inches of shielding are required to provide accurate measurements of the activity on the inside surfaces of the piping and other components. These measurements allow the activity levels both before and after the decontamination to be evaluated without interference from external contamination. Also, measurement of the radioisotopic composition will frequently provide an insight into the source of the residual activity. Hand-held directional probes and Cutie Pies are also required to locate hot spots (both internal and external to the reactor system) and to establish the environmental dose rates.

Measurements taken with these instruments must be integrated with the Ge( $\mathrm{Li})$ gamma scan data to provide a realistic interpretation of radiation level reductions obtained in the decontamination process. 


\section{REFERENCES}

1. Vandenberg, S. R., "Reactor Primary Coolant System Rupture Study-Quarterly Report No. 25," GEAP-10207-25, July-September 1971.

2. Hale, D. A., "Reactor Primary Coolant System Rupture Study-Quarterly Report No. 33," GEAP-10207-33, January-June 1975.

3. Palino, G. F., "Radioisotope Activities on BWR Primary System Piping I. Calibration of the General Electric Ge(Li) Pipe Gamma Scanning System," NEDC-12646-1, October 1976.

4. Anders, O. U., Private Communication, December 1976.

5. Burley, E. L., "Trip Report - Dresden, September 8-11, 1976," December 1976.

6. Harrison, G. J., Private Communication, December 1976. 
APPENDIX A

SPOOL PIECE GAMMA SPECTRA - SECTION A 


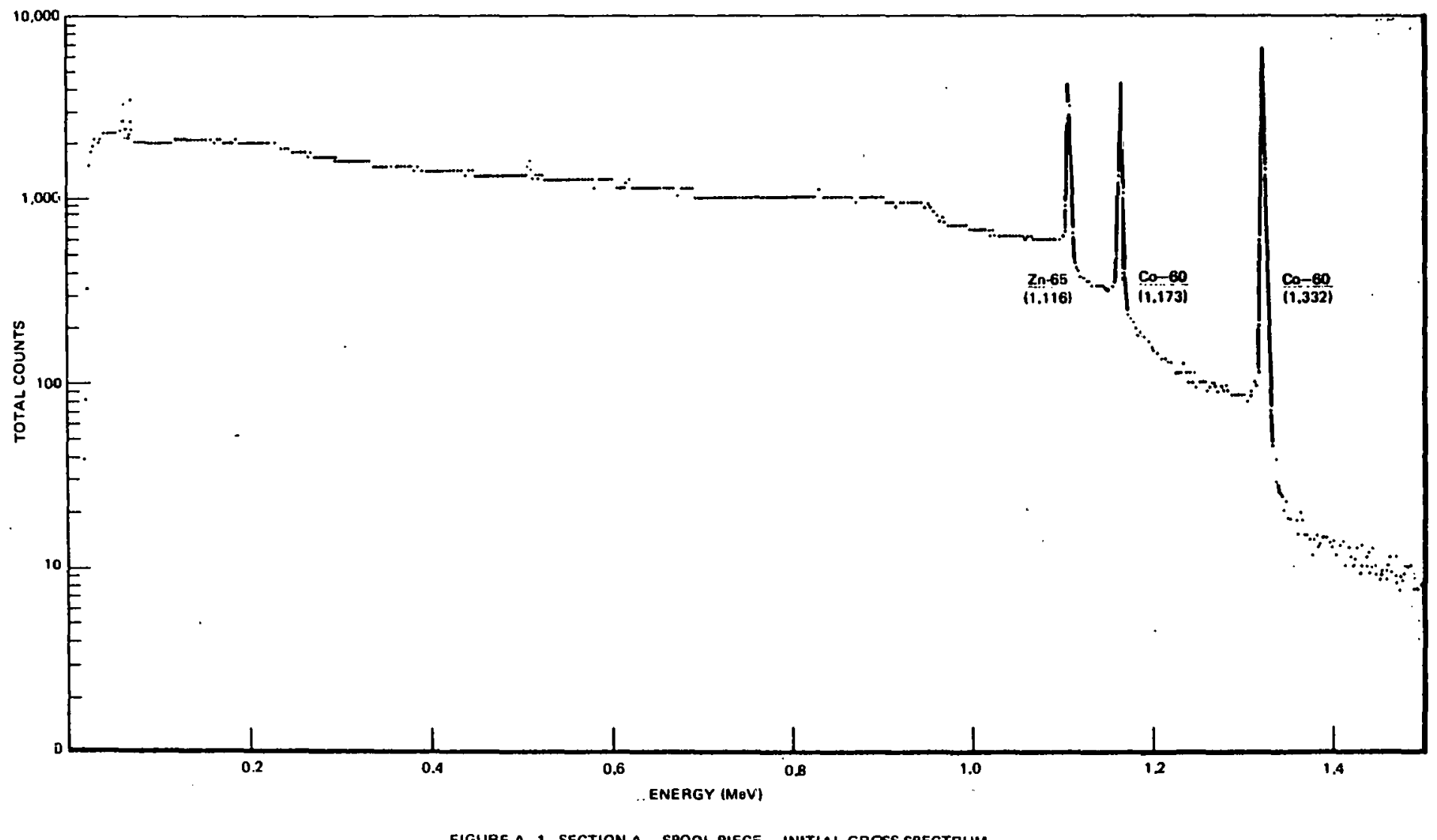




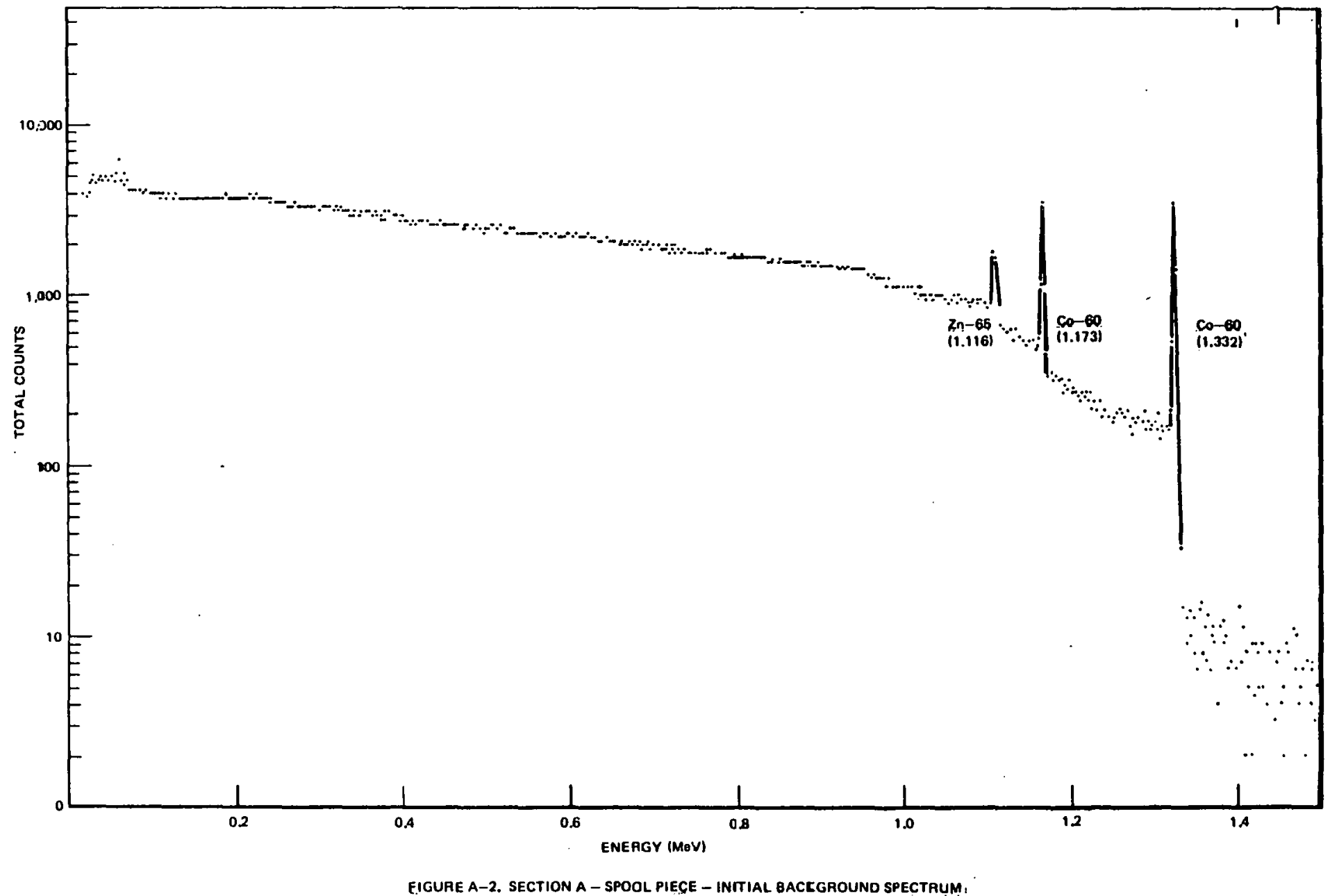




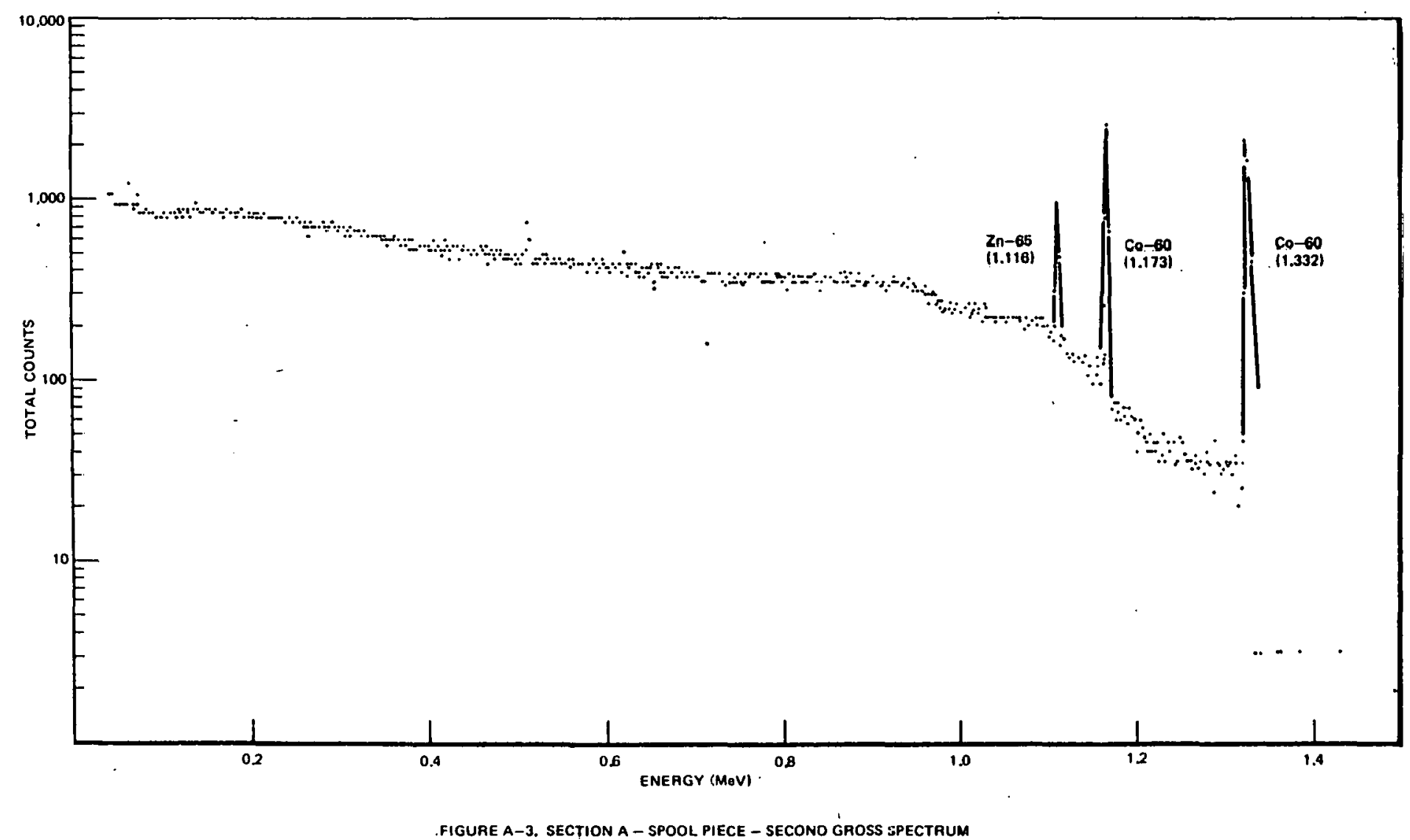




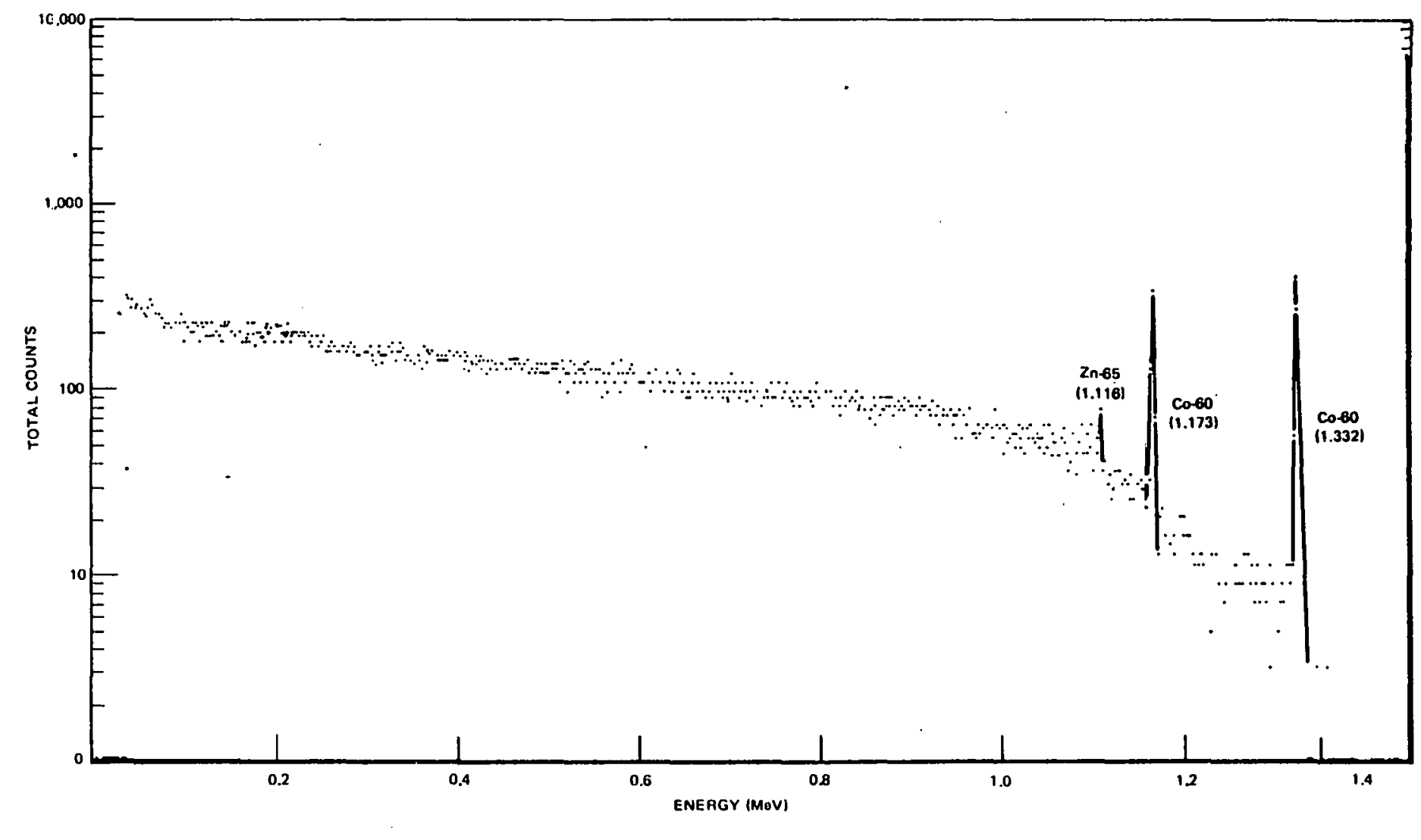

FIGURE A 4. SECTION A - SPOOL PIECE - SECOND BACKG』OUND SPECTRUM. 


\section{APPENDIX B}

PILOT LOOP GAMMA SPECTRA - LOCATION 3 


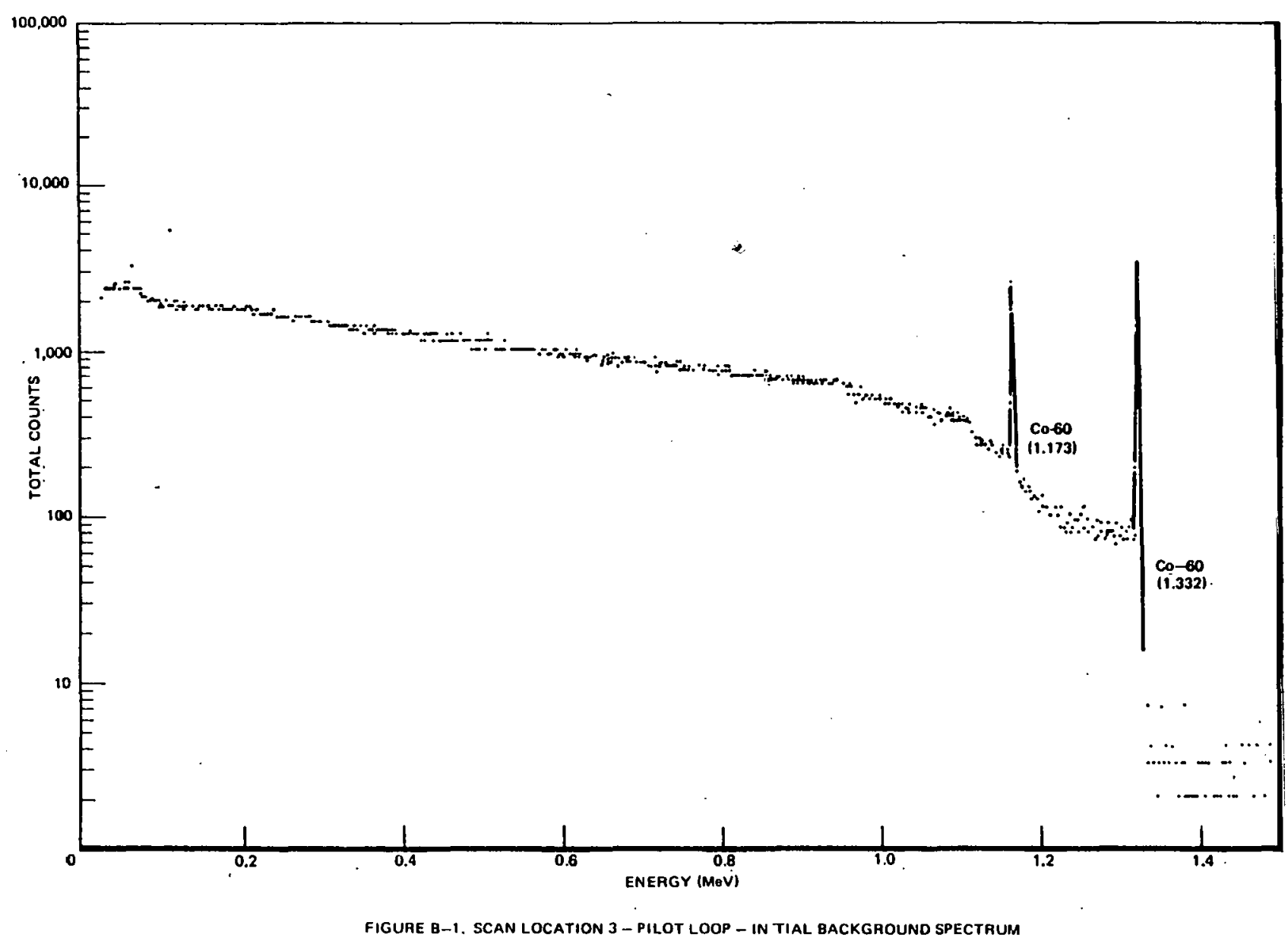




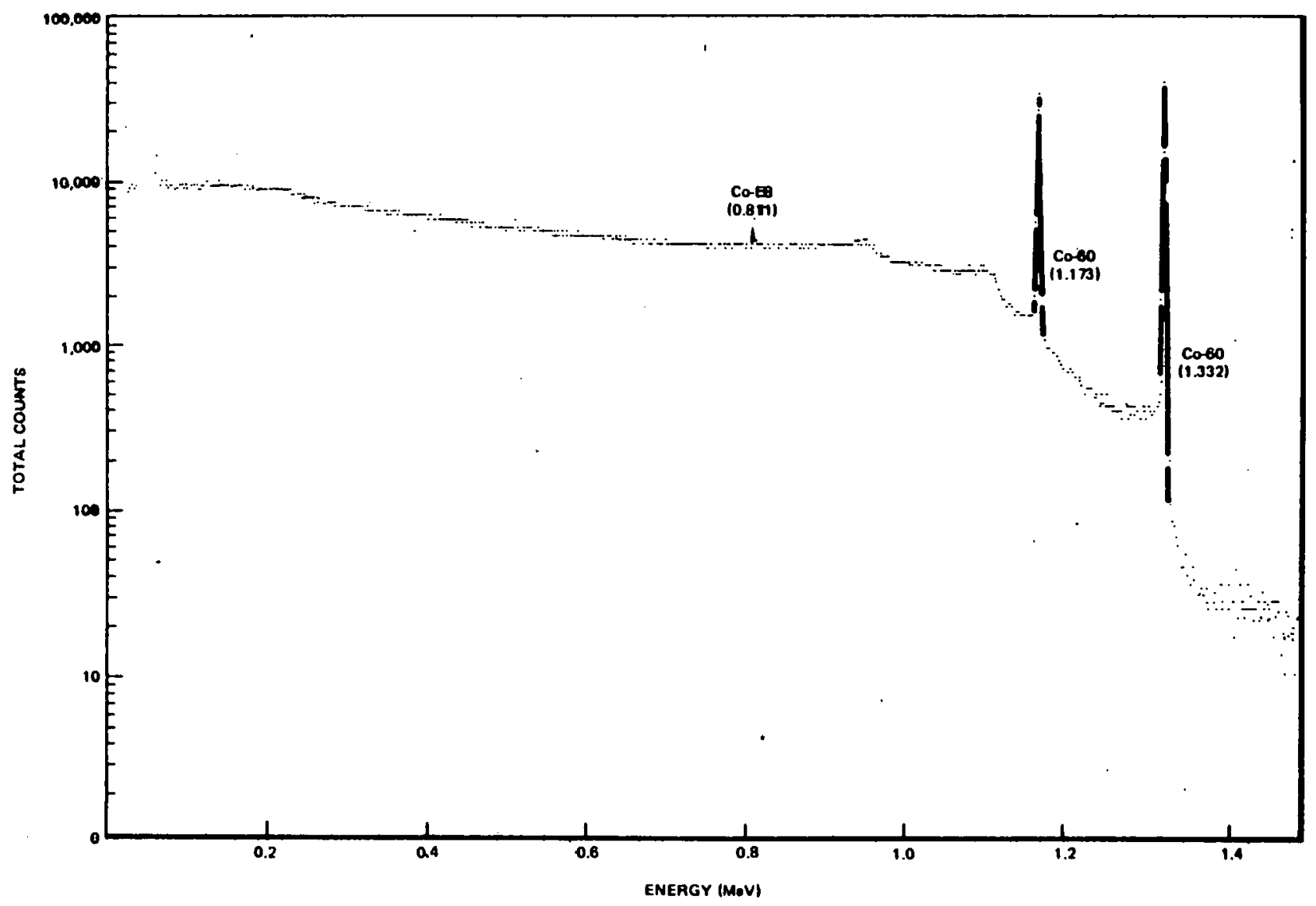

FIGURE B-2. SCAN LOCATION 3 - PILOT LOOP - INITIAL GROSS SPECTRUM 


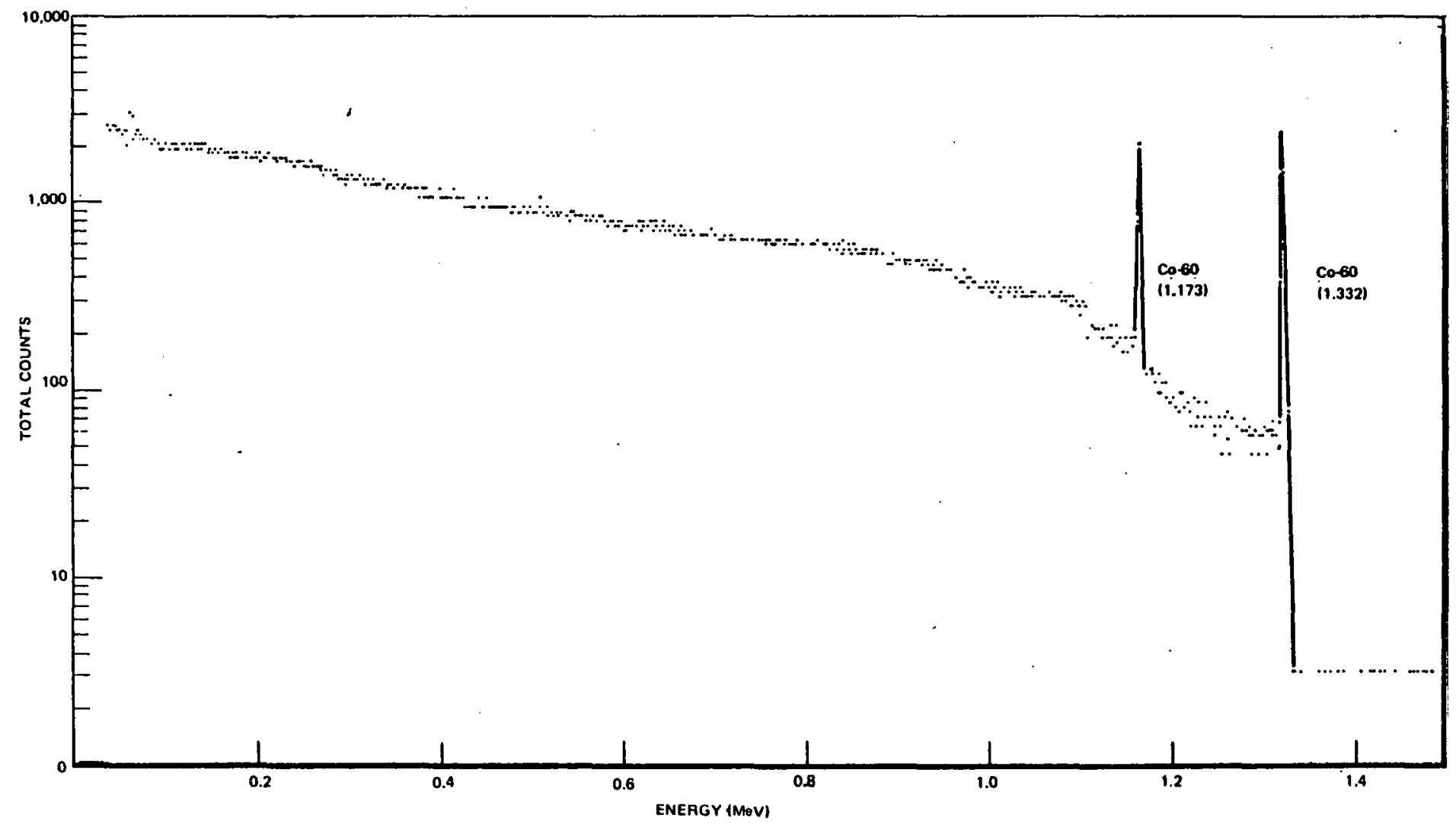

FiguRiE B-3. SCAN LOCATION 3 - PILOT LOOP - SECOND GROES SPECTRUM 


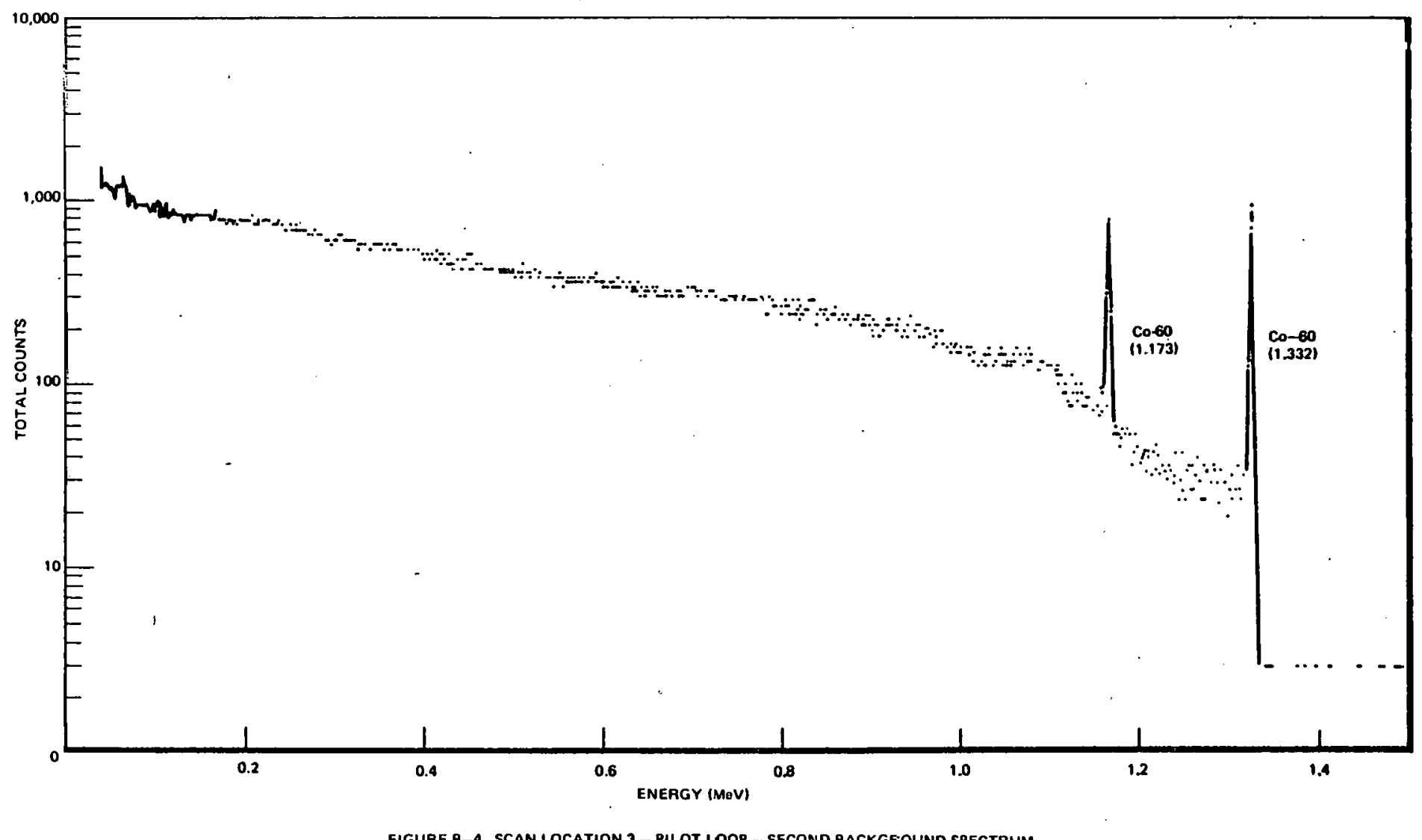

FIGURE 8-4. SCAN LOCATION 3 - PILOT LOOP - SECOND BACKGF:OUND SPECTRUM. 
EXTERNAL DISTRIBUTION

No. Copies

T. D. Boyce (DIS) 1

C. F. Chang (Argonne National Laboratory) 1

D. E. Harmer (DIS) 2

G. J. Harrison (CECO) Dresden Station 1

W. I. Kiedaisch (CECO) 2

T. C. Quaka (CECO) 1

R. Staehle (O.S.U.) 1

W. P. Worden (CECO) 2

G. P. Wagner (CECO) 2

J. S. Graves (CECO) 5 